ANL/ES-58

Environmental Control Technology and Earth Sciences (UC-11)

\author{
ARGONRE MATIONAL LABORATORY \\ 9700 South Cass Avenue \\ Argonne, Illinois 60439
}

\title{
GREAT LAKES WATERS: \\ RADIATION DOSE COMITTENTS, POTENTIAL HEALTH \\ EFFECTS, AND COST-BENEFIT CONSIDERATIONS
}

\author{
E. John Ainsworth* \\ (Project Manager)
}

\section{Contributors:}

E. John Ainsworth* Thomas B. Borakt* David N. Edgington ${ }^{t}$ Walter E. Kisieleski Tobey L. Winters Alan M. Wolsky Yuchien Yuan ${ }^{\dagger+}$
Radiobiology Physics and Dosinetry Enviromental Chenistry Radiochenistry and Radiobiology Cost-Benefit Analysis Cost-Benefit Analysis Biophysics and Dosinetry

Division of

Environmental Impact Studies

July 1977

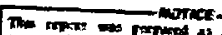

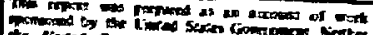

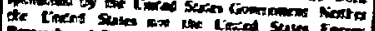

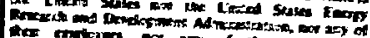

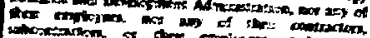

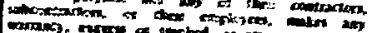

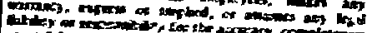

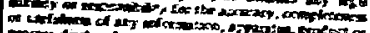

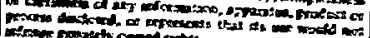

*Present address: The Donner Laboratory, University of Californid, Lawrence Berkeley Laboratory, Berkeley, CA 94720

**Present address: Colorado State University, Fort Collins, Co 80523 TDivision of Radiological and Environmental Research, AML t†ETA, Inc., Dak Brook, IL 60521 


\section{FOREIORD}

The Great Lakes constitute a dominant geographical feature in North America and are a mor source of water for consumption by the large concentrations of people in the basin. The study herein reported includes an assessment of levels of redioactivity in the waters of the lakes. The report indicates dose Ievels aseoclated with water ingestion and provides a rational cvaluation of cleanup strategies. Euphasis has been placed on the covsequences of setting a maximum dose standard for drinking water that is taken from the Great Lakes, and on the feasibility of meeting the standard.

The difficulty of ascertaining the anount of radioactivity in the Great Lakes and the resultant dose levels associated with ingestion of the waters could well be characterized by a historical quotation:

Mathematicians are like Frenchmen: whatever you say to them they translate into their own language, and forthwith it is something entirely different. *

Nonetheless, the contributors to this report have produced a valuable yet concise supplement to the literature treating enviromental concerns--in this case, the welfare of residents consuning water In the Great Lakes basin.

July 1977

Bichard B. Keener, Editor

Division of Emvironmental Impact Studies

Argonne Vational Laboratory

Argonne, II 60439

*Johann Wolfgang von Goethe (German poet and dramatist) 1749-1832. 


\section{ACKNOWLEDG ENIS}

We acknovledge consultations with Drs. John $\mathrm{H}$. Marshall, Andrew F. Stehney, and William P. Norris of Argonne National Laboratory and $D r$. K. Y. Hong of Ontario Bydro regarding retention functions and dose calculations. Contributions from Dr. J. L. S. Saguinsin of Argonne lational Laboratory are appreciated. 


\section{CONIENIS}

Page

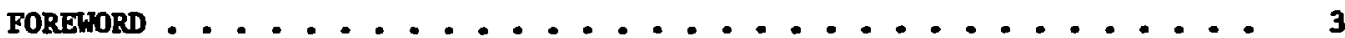

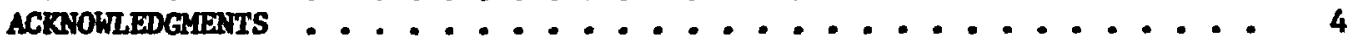

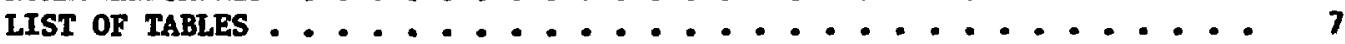

ABSTRACT ................................. 9

1. INTRODUCTION ........................... 9

2. THE REVISED RADIOACTIVITY OBJECTIVE . . . . . . . . . . . . 10

3. BACKGROUND ........................... 10

3.1 Dose from Internal Enftters . . . . . . . . . . . . . . 10

3.2 Definition of TED $_{50}$. . . . . . . . . . . . . . . . . . . 11

I 3 Dose-Response Relationships and Health Effects . . . . . . . . . 13

4. RADTONUCLIDES IN GREAT LAKES WATER . . . . . . . . . . . . . . 13

4.1 Radiolsotope Concentrations . . . . . . . . . . . . . . . 13

4.2 Natural and Man-Made Sources of Radioactivity . . . . . . . 16

4.3 Isotope-Inventory Projections to 2050 . . . . . . . . . . . . 17

$4.4{ }^{137}$ Cesium Concentration in Fish . . . . . . . . . . . . . . 19

4.5 Recomendations for Monitoring Lake Waters . . . . . . . . . . 19

5. TED 50 CALCULATIONS ........................ 20

$5.1 \mathrm{TED}_{50}$ Estimates Based on Consumption of 2.2 Liters of

Lake Water for One Year ... . . . . . . . . . . . . 20

5.2 Conclusion . . . . . . . . . . . . . . . . . . . . . 21

5.2.1 TED 50 Estinates Exceed One-Hilliren Objective . . . . . . . 21

5.2.2 Comparison of TED $_{50}$ Estinates after One Year and

50 Years of Water Ingestion ................ 22

5.3 Dose Perspectives . . . . . . . . . . . . . . . . . 24

6. COST-BENEFIT CONSTERATIONS . . . . . . . . . . . . . . . 26

6.1 Introduction ........................... 26

6.1 .1 Scope of Considerations ................... 26

6.1 .2 Organization .......................... 26 


\section{CONIENIS}

Page

6.2 Health Effects . . . . . . . . . . . . . . . . . . 27

6.2 .1 Introduction ........................ 27

6.2 .2 The Possible Harms ....................... 27

6.2.3 The Probabllity of Harm per Dose . . . . . . . . . . . 27

6.2 .4 Dose per Concentration ..................... 28

6.3 The Value of Risk Reduction . . . . . . . . . . . . . . 29

6.3 .1 Introduction . . . . . . . . . . . . . . . . . 29

6.3 .2 Relation of Risk to Earnings . . . . . . . . . . . . . . 30

6.3.3 The Value of Reducing the Concentration of ${ }^{226} \mathrm{Radium}$ in Drinking Vater ..................... 31

7. STRATEgIES ON CLEAKUT . . . . . . . . . . . . . . . . . . 32

7.1 Input Sources and Cleanup Emphasis . . . . . . . . . . . 33

7.2 Estimate of ${ }^{226}$ Radiun Input fron Fertilizer and Phosphate

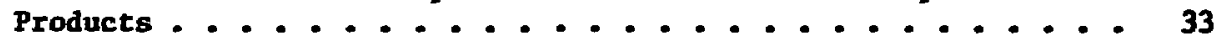

7.3 Removal of ${ }^{226}$ Radiun from Phosphate and Uranium Products . . . 35

7.4 Removal of ${ }^{226}$ Radium fron Drinking Water . . . . . . . . . . . 36

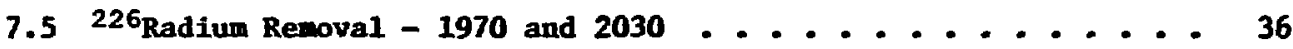

7.6 The Costs of Drinking-Water Treatment . . . . . . . . . . . 37

8. COST-BENEFIT SUMARY . . . . . . . . . . . . . . . . . 39

9. RECOARENDATIONS FOR FURTHER ASSESSMENTS BY THE DIVISION OP TECHWOLOGY OVERVIET (DTO) . . . . . . . . . . . . . . . . . 40

10. FUTURE RESEARCH NEEDS . . . . . . . . . . . . . . . . . 42

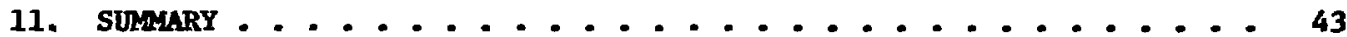

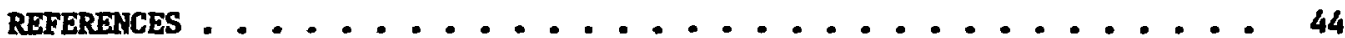

APPERIIX A . . . . . . . . . . . . . . . . . . . . . . . 47 


\section{TABLES}

No.

1. Dose Rates to Bone and whole Body after Ingestion of ${ }^{90} \mathrm{Sr}$ and ${ }^{226} \mathrm{Ra}$ for One Year and for 50 Years ...............

2. Concentrations of Radionuclides in the Great Lakes ....... 14

3. ${ }^{90} \mathrm{Sr}$ in Great Lakes Water ................... 14

4. Current Levels of Radioactivity in the Great Lakes ....... 15

5. Sumary of Dose Comitments that Result from Ingestion of $\mathbf{2 . 2}$ L1ters of Lake Water for One Year ............... 21

6. TED 50 from Radionuclides Measured in Lake Michigan Waters ..... 22

7. TED 50 from Racifonuclides Measured in Lake Huron Waters ...... 23

8. TED 50 fron Radionuclides Measured in Lake Ontarlo Waters ..... 23

9. TED $_{50}$ fron Radionuclides Measuced in Lake Erie Waters . . . . . 24

10. TED 50 from Maximm Peraissible Concentrations of Radioisotopes in Water ........................

11. TED 50 from a Radionuclide Concentration of One PIcocurie per Liter .......................

12. Estinated ${ }^{226}$ Radiun, Uraniun, and Thoriun Activity in Phosphate Fertilizer Products and By-Products Based on 1973 Wet-Process Production Data ................... 34

13. Total Treatment Costs per Year for the Great Lakes ....... 38

14. Sources of thole-Body Doses . . . . . . . . . . . . . 41

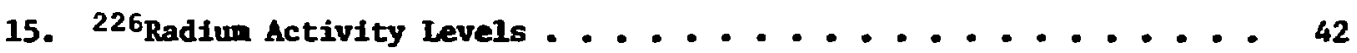

A. Parameters Used for Dose Calculations ............. 50 


\title{
GREAT LAKES WATERS: \\ RADIATION DOSE COMITMENT, POTEMTIAL HEALTH EFFECTS, AN COST-BEAEFIT CONSIDERATIONS
}

\author{
E. John Ainsworth - Project Kanager
}

\begin{abstract}
In 1972, a Great Lakes Water Qual ity Agreement was signed by the United States and Canadian Governments. It was stipulated that the operation and effectiveness of the agreement were to be reviewed comprehensively in 1977. Aspects of the agreement concern nondegradation of Great Lakes waters and maintenance of levels of radloactivity or other potential pollutants at levels considered as low as practicable. A refined radioactivity objective of one millirem is proposed in the Water Quality Agreement. The impl ications of adoption of this objective are not known fully. The Division of Environmental Impact Studies was commissioned by ERDA's Division of Technology Overview to summarize the information available on the current levels of radioactivity in Great Lakes waters, compute radiation-dose commitment (integrated dose over 50 years after consumption of 2.2 liters of water for one year), and to comment on the feasibility and cost-benefit considerations associated with the refined one-millirem objective. Current levels of radioactivity in the waters of Lakes Michigan, Ontario, Frie, and Huron result in dose commitments in excess of 1 mrem for whole body and 6 mrem for bone. Future projections of isotope concentrations in Great Lakes water Indicate similar dose commitments for drinking water in the year 2050. Reduction of the levels of radioactivity in Great Lakes waters is not feasible, but cost-benefit considerations support removal of ${ }^{226} \mathrm{Ra}$ and ${ }^{90} \mathrm{Sr}$ through interceptive technology before water consumption. Adoption of the one-millirem objective is not propitious.
\end{abstract}

\section{INIRODUCTION}

The purpose of this short-tern project is to prowide the Division of Technology Overview (DTO), Energy Research and Developwent hdninistration (ERDA), with a sunary of radioisotope concentrations and resulting total equivalent dose-50 years (IED 50 ) that would result from consuning 2.2 liters of untreated lake water per day. Radiodsotope concentrations in lake water 
are summarized from readily available data sources only, and TED 50 estinates are calculated. The $T \mathrm{TD}_{50}$ estinates are discussed in the context of a refined radioactivity objective for the Great Lakes based on TED $_{50}$ of one all11rem. Future projections of radiofsotope concentrations in like waters are mide. Potential health effects, specifically cancers and wtations, that could result from current and projected levels of radioactivity in Great Lakes water are estimated. Action alternatives, such as the feasibility and cost ve. benefit of reducing the levels of radioactivity in lake water, are discussed. Deficiencies in the existing data and monitoring prograns, and the insufficient understanding of lake-water dynanics and ecology, are also discussed. Final emphasis is placed on the inadvisability of adoption of a refined radioactivity objective of $T E D_{50}$ equal to one millirem, based on the current state of Information regarding radioactivity in Great Iakes water.

\section{THE REVISED RADIOACTIVITY OBJECTIVE}

Consideration of "dose* objectives" from radioisotopes, contained in Great Lakes water, needs to be inproved substantially by: (1) accurate determination of the present radiofsotope inventory; (2) quantitative identification of the input sources of radioactivity; and (3) evaluation of any natural processes, viz., concentration of suspended solids, sedimentation, concentration in aquatic organison, or lake flushing, whch ma influence water quality.

Implicit in the concept of a water-quality objective is the matter of control, nondegradation, or possibly reduction in pollution levels. Explicit is the fact that only man-made sources of input are subject to interceptive control alternatives "before the fact." These matters must be addressed directly before serious deliberations on water-quality objectives are begun. The large uncertainties and incomplete information about existing radiofsotope concentrations in lake waters result in correspondingly uncertain estimates of TED $_{50}$.

\section{BACKGROUND}

\subsection{DOSE FROM INTERMAL EMTTTERS}

Relationships between concentration of ingested radioisotopes and biological effects are particularly difficult to predict for internally deposited radionuclides. The difficulties of the conversion from concentration to dose arlse from the very complex relationships between incorporation of isotopes Into the body, their distribution in varicus body fluids, organs, or tissues, and their excretion. Dose to cells at risk for carcinogenesis or utagenesis can only be estinated in most cases.

Doses from the isotopes present in lake waters are estinated through complex equations Involving absorption, transfer, retention coefficients for

*In this docuent, dose refers to absorbed dose and radiation quality and is expressed in rem. 
radiolsotopes, and qualicy factora for the radiations enitted-reconended by ICRP-II, ICRP-20, and ICRP-23. These equations represent the current stateof-the-art. Subcomittees of both ICRP and RCRP take full cognizance of emerging data and nev concepts that may influence internal-dose calculations. The staff is advised that new formulations are currently under stud;, and we emphasize that reevaluations of dose estinate way be necessary wen new recommendations becone available. Using the formulations described in Appendix $A$, we provide dose estinates for thole body, bone, and gonads. A Quality Factor (QF) of ten is assuned for all alpha emitters. Whole-body dose is based on total effective energy deposited in a 70-kg standard man. Bone dose is computed based on total effective energy deposited in a bose mass of $7 \mathrm{~kg}$. An additional wodifying factor of five is used for all bone-seeking alpha- and beta-entting nuclides except when ${ }^{226} \mathrm{Ra}$ is the first nember of the decay chain. Gonadal dose is based on wole-body dose, but is integrated over 30 years rather than 50 years. The dose comitment to gonads from $226_{\mathrm{Ra}}$ Includes a modifying factor of 0.2 to take into account the ratio of massabsorption coefficients and geometical factors between bone and soft tissue. Thus, for Identical tine integrals, the gonadal dose is a factor of 50 lower than the bone dose. 1

Based on the isotope inventorles in Great Lakes waters, dose to bone from ${ }^{90} \mathrm{Sr}$ and ${ }^{226} \mathrm{Ra}$ is of greatest significance. Bone is the organ at risk for carcinogenesis and any dose criteria contemplated should be based on dose to bone and gonads. The use of total-body dose from the isotope distribution In lake water is biologically meaningless.

\subsection{DEFINITION OF TED 50}

The revised radioactivity standard for Great lakes vaters is based on $\mathrm{TED}_{50}$. In a sense, this is a comendable gesture because health effects, such as cancer and wutagenesis, depend on "dose" or energy absorbed by the tissues at risk. However, we stress that relat:onships between dose (sustained at low dose rates) from internal enitters and biological effects remain poorly understood. The Argonne staff believes that relationships between incorporated activity and biological effect are better understood. Perhaps more Important to this report, the definition and usage of TED $_{50}$ is not totally consistent among the various docusents revieved. This inconsistency may concribute to differences of opinion regarding the biological significance of the levels of radioactivity currently present in, or projected for, the Great Lakes.

One issue is the relationship between TED 50 and annual dose rate. Quoting from the Federal Register, 42(65) 5 April 1977, "This water quality level is expressed in terms of the total equivalent dose to ICRP reference man integrated over 50 years: $\left(T E D_{50}\right)$. It is proposed that water quality outside of any source control area, as defined herein, shall not result in a $T_{50}$ greater than one wren to the whole body from dafly ingestion of 2.2 1iters of lake water for one year. Therefore, even for lifetine (50 years) ingestion, the annual doge rate will not exceed 1 mrea/year." The Argonne staff considers the last sentence regarding the annual dose rate to be misleading. We believe the sentence should state that, for continuous ingestion for 50 years, the dose received in any given year will not exceed 1 wrem. 
Quoting from the Public Notice from the Department of State concerning the report of the International Working Group on Radiaactive objective for Great Lakes Water Quality, TED 50 is defined as follows: "For the purpose of this report, the total equivalent dose to a particular organ, tisaue, or whole boay is the accurulated dose equivalent over 50 years resulting from the daily Ingestion of 2.2 1iters of lake water for one year." The expression is $\mathrm{TED}_{50}=\mathrm{Ii} \mathrm{D}_{501} \mathrm{Q}_{1} \mathrm{H}_{1}$ rew; were $\mathrm{D}_{501}$ 3quals total absorbed dose integrated over a period of 50 years after intake of radionuclide "i", Qi equals quality factor, and $\mathrm{N}_{1}$ equals the product of all other codifying factors. Note that annual dose rate 18 not wentioned.

Quoting fram Appendix $D$ of the draft of the Fifth Annual Report of the Radioactivity Subcomittee of the Water Quality Board"s Implenentation Comittee (p. 37, para. 3, Iine 4), "The annual radiological dose $\left(\mathrm{TED}_{50}\right)$ to the bone and an individual drinking the water at that point ...." Hote that $T_{50}$ is related to annual radiological dose, wereas there is no reference to annual dose in the State Departwent definition. The Argonne staff objects to quoting annual dose rates. Over a period of 365 days, the dose rate ay change considerably. To illustrate this point, Iable 1 shows the dose rate per day from ${ }^{90} \mathrm{Sr}$ and ${ }^{226} \mathrm{Ra}$ to bone and hole body for continuous intake and for several instances of one-year intake after several tine intervals.

Table 1. Dose Rates to Bone and whole Body after Ingestion of ${ }^{90} \mathrm{Sr}$ and $226 \mathrm{Ra}$ for One Year and for 50 Years (at one picocurie per 1iter)

\begin{tabular}{|c|c|c|c|c|c|c|c|c|c|}
\hline \multirow{3}{*}{$\begin{array}{l}\text { Retention } \\
\text { Punction }\end{array}$} & \multirow[b]{3}{*}{ 2sotope } & \multicolumn{8}{|c|}{ Intermel (yere) } \\
\hline & & \multicolumn{4}{|c|}{ Oneyenr fesidncy } & \multicolumn{4}{|c|}{ 50-year actidency } \\
\hline & & 1 & 10 & 30 & so & 1 & 10 & 30 & 50 \\
\hline \multicolumn{10}{|c|}{ 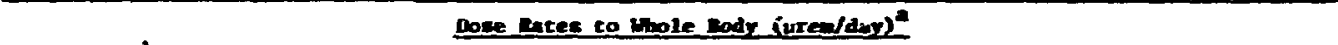 } \\
\hline Exponent $11^{b}$ & ${ }^{90} \mathbf{S r}$ & 0.19 & 0.13 & 0.052 & 0.021 & 0.19 & 1.56 & 3.2 & 3.87 \\
\hline Power & ${ }^{90} \mathbf{S r}$ & 0.28 & 0.09 & 0.04 & 0.02 & 0.28 & 1.4 & 2.7 & 3.3 \\
\hline Exponential ${ }^{c}$ & 226 & 16.9 & 1.34 & 0.004 & 0.001 & 16.9 & 64.7 & 68.8 & 68.9 \\
\hline Power & 226 a & 0.98 & 0.15 & 0.09 & 0.06 & 0.98 & 3.0 & 5.1 & 6.6 \\
\hline \multicolumn{10}{|c|}{ Doce intes to lone (urealer) } \\
\hline Exponential & $9^{9} \mathbf{r}$ & 2.9 & 2.0 & 0.9 & 0.4 & 2.9 & 24 & 51 & 64 \\
\hline Pourer & ${ }^{90} \mathbf{S r}_{\mathbf{r}}$ & 2.8 & 0.9 & 0.4 & 0.2 & 2.8 & 14 & 27 & 33 \\
\hline Exponentiale & 2267 & 25 & 22 & 16 & 12 & 25 & 239 & 617 & 892 \\
\hline Power & $226=$ & 9.8 & 1.5 & 0.8 & 0.6 & 9.8 & 30 & 51 & 66 \\
\hline
\end{tabular}


Because the water-quality objective is defined in terms of TED 50 , and TED $_{50}$ estimates can be translated to health effects to predict environmental impacts, the staff emphasizes that total dose commitment after any one-year consumption of water pruvides an unrealistic estimate of dose and of effect. Integration of dose for 30-50 years of water consumption provides a more realistic assessment of potential health effects.

If the Senior Review Group or any other deliberative body uses a waterquality objective defined in terns of $\mathrm{TED}_{50}$, unambiguous definition is required. The Argonne staff fails to understand how the Radioactivity Subcomittee could press strongly for adoption of the one-millirem ohjective when: (1) confusion over definition and conputation of TED 5 is apparent; (2) most of the nonitoring daca evaluated by them is recognized as wholly inadequate for dose computations; (3) $\mathrm{TED}_{50} \mathrm{~s}$ that result from drinking lake water in 1977 were not known accurately by then due to incomplete identification of isotope inventories at the time the one-milliren objective was enunciated; and (4) TED 50 , based on one-year water consumption, is useful only for comparative purposes and underestimates potential health effects by a large margin. Based on these considerations, we feel that adoption of the one-millirem objective is premature.

\subsection{DOSE-RESPONSE RELATIONSHIPS AND HEALTH EFFECTS}

Exposure standards or objectives for lonizing radiations, or any other environmental toxicant, focus on protection of the public health with the intention of minimizing adverse health effects. Ali huan activities involve some element of risk, and standards for environentally significant toxicants should be set based on consideration of potential adverse health effects viewed in the perspective of potential benefits to the society. Because definitive data derived from epidemiologic studies of human populations, or from animal studies, are lacking with respect to the acceptance or rejection of a linear relationship between adverse health effects and radiation dose, the linear relationship is used conventionally for risk estination for both somatic and genetic effects of ionizing radiations (BEIR Report). This action has been considered prudent by various comittees charged with recommendations for risk estimation. Definitive data do not exist to confirm or reject the hypothesis of linearity at doses below 50-100 rem received at $10 \mathrm{w}$ dose rates and over long periods of time.

\section{RADIONLCLIDES IN GREAT LAKES MATER}

\subsection{RADIOISOTOPE CONCENTRATIONS}

The concentrations of radionuclides $(\mathrm{pCi} / 1)$ in the waters of the Great Lakes are summarized in Tables 2-4. Tables 2 and 3 were compiled by Dr. D. N. Edgington, and Table 4 by the staff of the Division of Environmental Impact Studies. Table 4 compiles the sumarized results from Tables 2 and 3 and the essentially unpublished monitoring data that have been provided to the Radioactivity Subcomittee of the Great Lakes Water Quality Board. The accuracy and precision of the data and detection linits given in these reports are unknown and have not been evaluated by the Radioactivity Subcomnittee. The values in parenthesis for ${ }^{226}$ la for Lake Huron (Table 4) 
Table 2. Concentrations of Radionuclides in the Great Lakes a (pCl/1)

\begin{tabular}{|c|c|c|c|c|c|c|}
\hline \multirow[b]{2}{*}{ Date } & \multirow[b]{2}{*}{ Nuclide } & \multicolumn{5}{|c|}{ Lake } \\
\hline & & Superior & Michigan & Buron & Erie & Ontario \\
\hline $1950 \mathrm{~s}$ & $\begin{array}{l}226 \mathrm{Ra} \\
210_{\mathrm{Pb}}\end{array}$ & & $\begin{array}{l}0.02^{b} \\
0.03\end{array}$ & & & $0.04^{c}$ \\
\hline 1972 & $\begin{array}{r}40_{K} \\
{ }^{3} H\end{array}$ & & $285^{1.4}$ & & & \\
\hline 1973 & $\begin{array}{r}90 \mathrm{Sr} \\
137 \mathrm{Cs} \\
239_{\mathrm{Pu}} \\
238_{\mathrm{Pu}}\end{array}$ & $\begin{array}{l}0.53 \\
0.07 \\
0.0006\end{array}$ & $\begin{array}{l}0.81 \\
0.05 \\
0.0007 \\
0.00003\end{array}$ & $\begin{array}{l}0.96 \\
0.04^{d} \\
0.0006\end{array}$ & $\begin{array}{l}1.1 \\
0.02 \\
0.0002\end{array}$ & $\begin{array}{l}1.3 \\
0.03 \\
0.0002\end{array}$ \\
\hline 1976 & $\begin{array}{r}90 \mathrm{Sr} \\
137 \mathrm{Cs} \\
239 \mathrm{Pu}\end{array}$ & & $\begin{array}{l}0.89 \\
0.05 \\
0.0006\end{array}$ & $\begin{array}{l}0.88 \\
0.031 \\
0.0005\end{array}$ & $\begin{array}{l}1.0 \\
0.013 \\
0.0002\end{array}$ & $\begin{array}{l}1.2 \\
0.02 \\
0.0003\end{array}$ \\
\hline \multicolumn{7}{|c|}{$\begin{array}{l}\text { anless otherwise indicated, values for these nuclides may be found in arti- } \\
\text { cles in RER Division Annual Reports 1972-1975, ANL-7960 part III, ANL-8060 } \\
\text { Part 3, ANL 75-3 Part III, and ANL 75-60 Part III. } \\
b_{\text {A. Stehney and H. Lucas, Proc. Int. Conf. Peaceful Dses At. Energy Geneva }} \\
11: 49-54,1956 \text {. } \\
c_{J} \text {. Hursh, NuCleonics } 7: 45-59,1950 \text {. } \\
d_{\text {From P. J. Barry, IAEA Symp. On Environ. Behavior of Radionuclides Released }}\end{array}$} \\
\hline
\end{tabular}

Table 3. ${ }^{90} \mathrm{Sr}$ in Great Lakes Water (pCi/1)

\begin{tabular}{cccccc}
\hline & \multicolumn{5}{c}{ Lake } \\
\cline { 2 - 6 } Date & Superior & Nichigan & Huron & Erie & Ontario \\
\hline 1973 (observed) & 0.53 & 0.81 & 0.96 & 1.1 & 1.3 \\
(calculated) & 0.55 & 0.89 & 0.90 & 0.89 & 1.2 \\
1976 (observed) & - & 0.89 & 0.88 & 1.02 & 1.2 \\
$\quad$ (calculated) & 0.55 & 0.88 & 0.88 & 0.83 & 1.1 \\
2050 (calculated) & 0.58 & 0.73 & 0.67 & 0.62 & 0.61 \\
\hline
\end{tabular}


Table 4. Current Levels of Radioactivity in the Great Lakesa (pci/1)

\begin{tabular}{|c|c|c|c|c|c|c|}
\hline \multirow[b]{2}{*}{ muclide } & \multicolumn{5}{|c|}{ Eake } & \multirow[b]{2}{*}{$M P C^{d}$} \\
\hline & Mrchiganb & suparior & Murade & Erie & Oatario & \\
\hline $40 k$ & (1.4) & & & & & \\
\hline${ }^{3} \mathbf{B}$ & $200-900 \quad(285)$ & 350 & $1700-30,300$ & $300-400$ & $700-2530$ & $3 \times 10^{7}$ \\
\hline${ }^{90} \mathrm{Sr}$ & $0.7-0.9(0.81)$ & & $0.61-1.07$ & $0.9-1.15$ & $0.87-1.0$ & $3 \times 10^{2}$ \\
\hline${ }^{137} \mathrm{Cs}$ & $(0.05)$ & $0.071-0.079$ & $0.024-0.020$ & $<0.07$ & $0.06-0.12$ & $2 \times 10^{4}$ \\
\hline $239,240 \mathrm{Pu}$ & $(0.0007)$ & & & & & $5 \times 10^{3}$ \\
\hline $23 \theta_{\mathrm{U}}$ & 0.1 & & & & & $4 \times 10^{4}$ \\
\hline $234 \mathrm{U}$ & 0.1 & & & & & $3 \times 10^{4}$ \\
\hline 22620 & $(0.02)$ & & $0.1-3.0(5-11)$ & $0.03^{e}$ & $<1.0-5.5$ & $3 \times 10^{1}$ \\
\hline $210_{\mathrm{Pb}}$ & $(0.03)$ & & & & & $1 \times 10^{2}$ \\
\hline $210^{\circ o}$ & & & & & & $7 \times 10^{2}$ \\
\hline $125 \mathrm{Sb}$ & & $0.024-0.050$ & $0.035-0.107$ & & & $1 \times 10^{5}$ \\
\hline $144 \mathrm{Ce}$ & 31 & $0.052-0.073$ & $0.030-0.379$ & $<0.2$ & & $1 \times 10^{4}$ \\
\hline${ }^{106} \mathrm{Ru}$ & & & & $<0.3$ & & $1 \times 10^{4}$ \\
\hline $45 \mathrm{Zr}$ & & & & $<0.1$ & $<0.3$ & $6 \times 10^{4}$ \\
\hline${ }^{134} \mathrm{Cs}$ & & & & $<0.05$ & $<0.08$ & $9 \times 10^{3}$ \\
\hline Gross alphe & & & $(8-40)$ & & $<1-45$ & \\
\hline Gross beta & $2-70$ & & $2-37 \quad(13-35)$ & $5-15$ & $1-47$ & \\
\hline
\end{tabular}

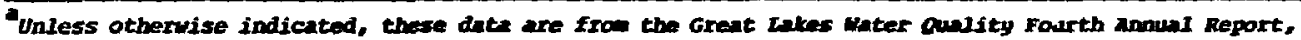
Appendix D. Annual Report of the Radianctivity Subconittes, June 1976. The accuracy and the preci-

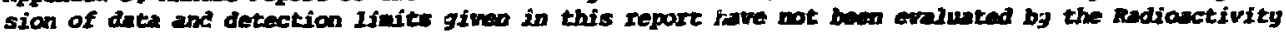
subcamittee.

barenthetical values ane frow rable 2.

Cparentbetical vaiues represent pabbule point-source reloups.

Arom appendix $\mathrm{B}$ of $10 \mathrm{CFR} 20$. Velues (uncontrolied aren-soluble) altiplied by $20^{\circ}$ to comert to n:E.2.

J. B. Hurfh, "The Rudium Content af Public watar Supplies," Rep. un-257, university of pochester, Rochester, NY, 2953.

represent values in Serpent Harbour on the North Channel of Lake Huron, which drains the El1lot Lake uraniu ining area of northern Ontario; these values were not included in dose calculations because te believe they are not a representative concentration for Lake Huron. Data in Table 4 include the results frov numetous radioactivity wontoring prograns that regularly check inshore surface waters and biota in the vicinity of operating nuclear facilities that have aqueous discharges to the Great Lakes. The open waters of the lakes are studied Irregularly, usually in connection with baseline or spectal studies, with no imediate plans to follow up on a regular basis. The extent to which these isotope concentrations are representative of openlake waters (outside source-control areas) or my be representative of water withdrawn for treatent and consumption is unknom. 
Included for comprative purposes in Table 4 are maxirum peraissible concentrations of the radionuclides in water as given in Appendix $B$ of 10 CFR 20 for uncontrolled areas.

As shown in Table 4, the radioisotope investory in all the lakes is incomplete, and large uncertainties are assoclated wth the values reported.

\subsection{MATURAL AND MAN-KADE SOGRCES OF RADIOACTIVITY}

The principal sources of radioactivity in Great Lakes waters are fallout frow nuclear weapons, the influx of natural radioactivity from ground or surface waters, medical or industrially used radioisotopes, and releases from the electrical-power industry and other industries utilizing nuclear or fossil fuels. Quantitative identification of source-teri contributions is beyond the scope of the current project, but the Argonne staff considers the Industrial and nuclear-power contributions swall relative to other sources of radioactivity.

It is necessary to distinguish between those muclides that are part of the natural radioactive-decay chains and those that have been introduced into the lakes since the onset of nuclear testing 30 years ago. The inventory for the latter radionuclides in the Great Iakes is relatively well knom as a result of the world-wide nonitoring of atwospheric fallout by the Health and Safety Laboratory, New York City. Studies of ${ }^{239} \mathrm{Pu},{ }^{137} \mathrm{Cs}$, and ${ }^{90} \mathrm{Sr}$ in Lake Hichigan have established that their concentrations are homogeneous throughout the water colum following the winter wixing perlod. Therefore, the numbers reported for these nuclides in Table 2 are for samples collected in the late spring. Samples from all the lakes in the spring of 1976 indicate that the concentrations of these three nuclides have not changed significantly during the three-year period.

Earlier work by Barry ${ }^{2}$ has shown that the concentration of ${ }^{137} \mathrm{Cs}$ ras far higher durfing the perfod (late 1960s) when the rates of input from fallout were far greater than now. The data suggest that the residence time of ${ }^{137} \mathrm{Cs}$ in the water colum was about one year. Because the present inputs are about 17 of the total inventory in the lake, and the concentrations of ${ }^{137} \mathrm{Cs}$ (and ${ }^{239} \mathrm{Pu}$ or ${ }^{90} \mathrm{Sr}$ ) are constant fro year to year, it appears that these three nuclides are in equilibriu within the system. Therefore, it might be expected that for ${ }^{90} \mathrm{Sr}$, where $96 \%$ of the total inventory is still in the water colum, the decrease in concentration will be largely controlled by the residence tine of watis in each of the Great Lakes and by radioactive decar. On the other hand, greater than $95 \%$ of the total inventory of ${ }^{137} \mathrm{Cs}$ and $239_{\mathrm{Pu}}$ is contained in the sejiments. If one assures that their concentrations in the water column are controlled by a distribution coefficient between sediment and water $\left(K=\mathrm{pC}_{i} / \mathrm{g}\right.$ sediment per $\mathrm{pCI} / \mathrm{ml}$ water $\left.\underline{2} 2 \times 10^{5}\right)$, the decrease in concentration in the water wil be controlled largely by the rate of burial of old sediment with new. The sedimentation rates in the Great lakes vary between $>1.0 \mathrm{yr}$ to $<1.0 \mathrm{~cm} / \mathrm{yr}$ and the situation is complicated by redistribution of sediments by bloturbation and remobilization by in-1ake physical processes. It is therefore difficult to predict accurately the tine span over which the concentrations of ${ }^{137} \mathrm{Cs}$ or ${ }^{239} \mathrm{Pu}$ will decrease in the water column. 
In contrast to the wealth of detall available concerning the behavior of fallout radionuclides in the lakes, little is known concerning the behavior of the natural radionuclides; in fact, it is not clear that even the concentrations of the more inportant nuclides are know to even one order of magnitude. This becones clear when an attempt is made to coupare the results of analyses for ${ }^{226} \mathrm{Ra}$, where values between 0.02 and $5.5 \mathrm{pCi} / 1$ have been reported (Table 4). Up to now it has been assured that ${ }^{22 \overline{6}_{\mathrm{Ra}}}$ in the lakes is in equilibrium with its parent ${ }^{238} \mathrm{U}$ and, therefore, has a concentration in sediments of 1-2 pCi/g. Edgington and Callender ${ }^{3}$ showed that ${ }^{226} \mathrm{Ba}$ is concentrated up to $50 \mathrm{pCI} / \mathrm{g}$ in manganese nodules in Green Bay paralleling a similar enrichuent in barium. The sources of the exces $226_{R a}$ and barium were not established. There is no doubt that the inventory of $226 \mathrm{Ra}$ (and uranium) In the Great Lakes has to be increasing due to the extensive use of phosphate fertilizers and the burning of coal in the watersheds surrounding the lakes. What effects these additional loadings have had or might have on the consentration of ${ }^{226} \mathrm{Ra}$ in the water is unknown, but rust be evaluated. It is 'nown that there are inputs of ${ }^{226} \mathrm{Ra}$ to northern Lake Huron from uranium-processing mills in Ontario.

\subsection{ISOTOPE-INVENTORY PROJECTIONS TO 2050}

The concentration of ${ }^{90} \mathrm{Sr}$ as a function of tine in each lake way be calculated using the simple tine-concentration codel of Leraan, 4 provided that the inputs and the residence time for water in each lake are known. Whereas Lerman considered inputs from the watershed, it can be shom that a simpler model takirg account only of direct atmospheric deposition over the lake predicts the observed concentrations in the water colum from 1954 up to the present (Table 3). If it can be assumed that the present anpual rate of input of ${ }^{90} \mathrm{Sr}$ fallout (which is $\approx 1 \%$ of the total up to 1976) continues wei! into the next century, then the concentrations of ${ }^{0} \mathrm{Sr}$ in each of the lakes in 2050 will not be greatly different from those in 1976 (Table 3). We assume conservatively that by 2020 the concentration of $90 \mathrm{Sr}$ in Lakes Erie and Ontario should be very siuilar to those in Lakes Superior and Hichigan, 1.e. $\sim 0.2-0.3 \mathrm{pCi} / 1$, and by $2050 \sim 0.1-0.2 \mathrm{pCI} / 1$.

Concentrations of ${ }^{137} \mathrm{Cs}$ and ${ }^{239} \mathrm{Pu}$ will decrease slowly as their concentrations in the water colum appear to be controlled by equilibration with the sediments. Although we know the sedimentation rates quite accurately, the disappearance of activity in the sediments is not as fast as would be expected because of physical and biological nixing processes.

In the water colum the concentration of $226_{\mathrm{Ra}}$, which contributes a major fraction of the dose comitwent to ran, is poorly known at best. Little or nothing is known about the effasts on the concentration of $226_{\mathrm{Ra}}$ in the water colung due to fertiifrer runofí or inputs associated with flyash fron the burning of coal. On the basis of the ${ }^{90} \mathrm{Sr}$ data, indicating that this nuclide is retained in the water colum (96\% of the knom input from fallout to Lake Michigan is still in the vater colunn), there is a gall probability that increased agricultural usage of fertilizer in the watersheds and burning of coal may increase the concentration of $226_{\mathrm{Ra}}$ in the water colum. Based on these considerations $\mathrm{TED}_{50}$ values would not be expected to decrease in the near future. 
The concentration of ${ }^{210^{\mathrm{Pb}}}$ and $210^{\mathrm{Po}}$ is far higher than that expected to be in equilibrium with the ${ }^{22 \epsilon_{\mathrm{Ra}}}$ in the sediments, at least partly because of their formation frow ${ }^{222} \mathrm{Rn}$ in the atwosphere.

The operation of nuclear facilities such as reactors, fuel processing plants, urarium mining and nilling facilities, hospitals, and industrial and research facilities involves the regular release of all quantities of radionuclides and the sall but finite probability that major releases of radjoactivity my enter the environment as a result of an accident. The qualitative as well as quantitative nature of sone of these releases constitutes an area of sone uncertainty at the present tine. This is reflected in the paucity of input source-tern data for sone radionuclides and lack of specific data for certain lakes such as Lake Superior.

Real effects of present actions are not clear nor can effects be predicted of najor releases in drinking-uater supplies and those segments of aquatic food chains directly affecting man for a time equal to the lifetine of each radionuclide. This information is needed and w1l be inportant to develop site-by-site contiugency plans for water treatment, and the long-term usage of water from the Great Iakes.

As radionuclides affecting water quality enter principally from the atnosphere or from points on shore, their transport, chenical, physical, or biological transformations, and disposal throughout the lakes system are dependent on water novesents (largely turbulent) on a wide range of horizontal and vertical scales and on fluxes and transformations associated with living organisms and with interfaces (air/water, sedinent/water). Without adequate understanding of the relevant patterns, pathrays, and wechanisins, proper assesswent of predictive modeling of past or proposed managenent strategies will not be achieved nor will optim results be realized from expenditures for water-quality iprovenents, and protection will not be obtained.

Man-made radionuclides are widely used in nedical and biological research, diagnosis, and therapy, and in such uses where they have essentially replaced ${ }^{226} \mathrm{Ra}$, particularly in teletherapy units. Solid sources are used in telethciapy units and present little or no waste-disposal problem because they are enclosed in sealed containers and boused in permanent installations.

Internal use of radionuclides in therapy is restricted prinarily to lodine, phosphorus, technetiun, potassium, chronium, gold, carbon, and a few other short-1ived isotopes. In radiotherapeutic applications, the abovementioned radionuclides are generally utflized at illicurie levels. With lower dose levels (5-10 mCi) $10 \%$ to $15 \%$ may be excreted by the patient in the first day and smaller amounts thereafter. With higher levels ( 100 mCi), as in the case with ${ }^{131}$, as much as $60 \%$ to $70 \%$ nay be excreted in the first day. The wastes in the form of urinary or fecal excretion are generally discharged into the hospital serer.

In diagnostic studies, small anounts of radionuclides (10-100 $\mu \mathrm{CI})$ are used and add little to. hospital-effluent radioactivity levels. 
Disposal from research laboratories is difficult to follow except for control of the amount of a specific radionuclide. However, the problem is that of the radioactive waste discarded down sewer drains every day by laboratory workers; some nolecules (e.g. those that can be easily incorporated into DNA, the stable genetic material of genes and chromosomes) are far more likely to inflict biological danage than others of equal radioactivity, provided they find their way into food chains.

Because of the diversity of operations, general statements cannot be made on the volumes of waste and activity levels to be expected from industrial and medical facilities. Furthernore, gross-activity levels are quite meaningless becalise they provide no information on the specific nuclides present. In most cases, wonitoring information on the composition of waste discharges is linited, with only the more hazardous nuclides identified. Although these conditions are generally of some concern, within the context of the water-quality objective the concern is minor.

\section{$4.4{ }^{137}$ CESIUM CONCENTRATION IN FISH}

The only nuclide in lake waters that is known to concentrate significantly in fish (and, therefore, is important for dose to humans) is ${ }^{137} \mathrm{Cs}$. The concentration factor for this nuclide in 1971 was $\sim 5000$ (wet-weight basis). There is some evidence to suggest that this value of the concentration factor for "food-chain fish", such as steelhead, way be decreasing slightly even though no decrease in the water concentration has been detected.

Current Inventories of radionuclides in Lake Mchigan are:
Plutonium
ح $120 \mathrm{CI}$
(98\% in sediment)
$137 \mathrm{Cs}$
2 $6 \mathrm{kCi}$
(95\% in sediment)
${ }^{90} \mathbf{S r}$
2 $4 \mathrm{kCi}$
(4\% in sediment)

The current inventory of ${ }^{226} \mathrm{Ra}$ in lake water is $\sim 100 \mathrm{Ci}$ with $\sim 1 \mathrm{kCi}$ in the upper one centimeter of sediment. Similarly, the inventory of $210 \mathrm{~Pb}$ and $210_{\mathrm{Po}}$ is $150 \mathrm{Ci}$ in lake water and $27.5 \mathrm{kCi}$ in the upper one centimeter of sediment.

The availability of these nuclides in the sediments is governed by equilibrium between the water and sedinent, and even if all sources could be turned off, it is likely that the water would continue to contain radioactivity due to reequilibration.

\subsection{RECOMENDATIONS FOR MONITORING LARE WATERS}

We strongly recomend that a monitoring program be developed and implemented by the responsible agencies associated vith the Great Lakes Study. We also suggest that a standard protocol of radionuclide sampling and anaiysis be developed. Furtherwore, these procedures must be adhered to by tine various agencies or laboratories participating in surveillance programs. All monitoring data must be comiled in a uniform format and be easily accessible to all interested parties. 


\section{TED 50 CALCULATIONS}

Data from various sources, presented in Table 4, have been used to conpile 1sotope inventories and concentrations for the Great Lakes waters. As emphasized above, the accuracy of these seasurements is unknom. We sust reemphasize the incompleteness of the isotope-concentration data used for dose calculations so that dose estimates may be vieved in proper perspective.

Specific coments on definition of $\mathrm{TED}_{50}$ are in Section 3.2 , and methods by which TED50 values were computed are in Appendix A. Retention of ${ }^{90} \mathrm{Sr}$ and ${ }^{226} \mathrm{Ra}$ in bone, and the resulting dose comitments, follow complex functions. Exponentials and the power function have been used to describe retention for 1sotopes of alkaline-earth elements. The consensus is that the power function provides the best fit to existing data (Norris et al.5 and ICRP-20). The power function was used to compute dose comitments to whole body, bone, and gonads for these - sotopes. Considerably higher dose comitments would be inferred $\mathrm{fr}$-he use of exponential retertion functions.

\subsection{TED 50 ESTIMATES BASED ON CONSUUPTION OF 2.2 LITERS OF LAKE WATER FOR ONE YEAR}

The TED 50 values for whole body, bone, and gonads af ter Ingestion of water from the Great Lakes are sumarized in Table 5. Mo estinates for Lake Superior are provided due to insufficient data on concentration of $226 \mathrm{Ra}$. $\mathrm{TED}_{50}$ values for whole body, bon'a, and gonads (higher range) are in excess of the one-ailliren objective for all other Great Lakes. Because confifence limits of the concentration data used for dose calculations are unknown to the Argonne staff, the significance of excess above 1 mren cannot be estimated. Dose ranges, based on the isotope-concentration ranges given in Table 4, are presented for all lakes except Michigan. Isotope-concentration data given in Table 2 were used to compute IED $_{50}$ for Lake Hichigan water.

Based on avallable data, the TED 50 estinates for Lakes Michigan, Erie, and Huron (lower-range) approach the one-millirew objective for whole-body dose, but the higher-range values exceed the objective by an appreciable margin. The upper range of TED50s for whole-body doses for Lake Ontario exceeds the objective by factors of $~ 3-15$. Little significarice can be attached to the lower-range estinate of Lake Ontario because the concentration of ${ }^{226_{\mathrm{Ra}}}$ reported was $<0.1 \mathrm{pCi} / 1$; thus, $0.1 \mathrm{pCi} / 1$ was used in dose computation.*

Doses to bone are of the order of ten times higher than whole-body doses. The public notice published by the State Department states that "the total dose equivalent to a single organ or tissue shall be in proportion to the dose linit recomended by ICRP for that tissue." ICRP-15 considers gonads and red marrow as the critical organs for whole-body exposure, and provides limits of $5 \mathrm{rem} / \mathrm{yr}$ for those occupationally exposed, and $0.5 \mathrm{ren}$ for

\footnotetext{
* The Argonne staff has no explanation for the range of ${ }^{226} \mathrm{Ra}$ values reported in Table 4. Orders-of-magnitude differences between lakes would not be expected. Use of a standardized protocol for analytical methods is needed.
} 
Table 5. Sumary of Dose Cormitments that Result from Ingestion of 2.2 Liters of Lake Hater for One Yest

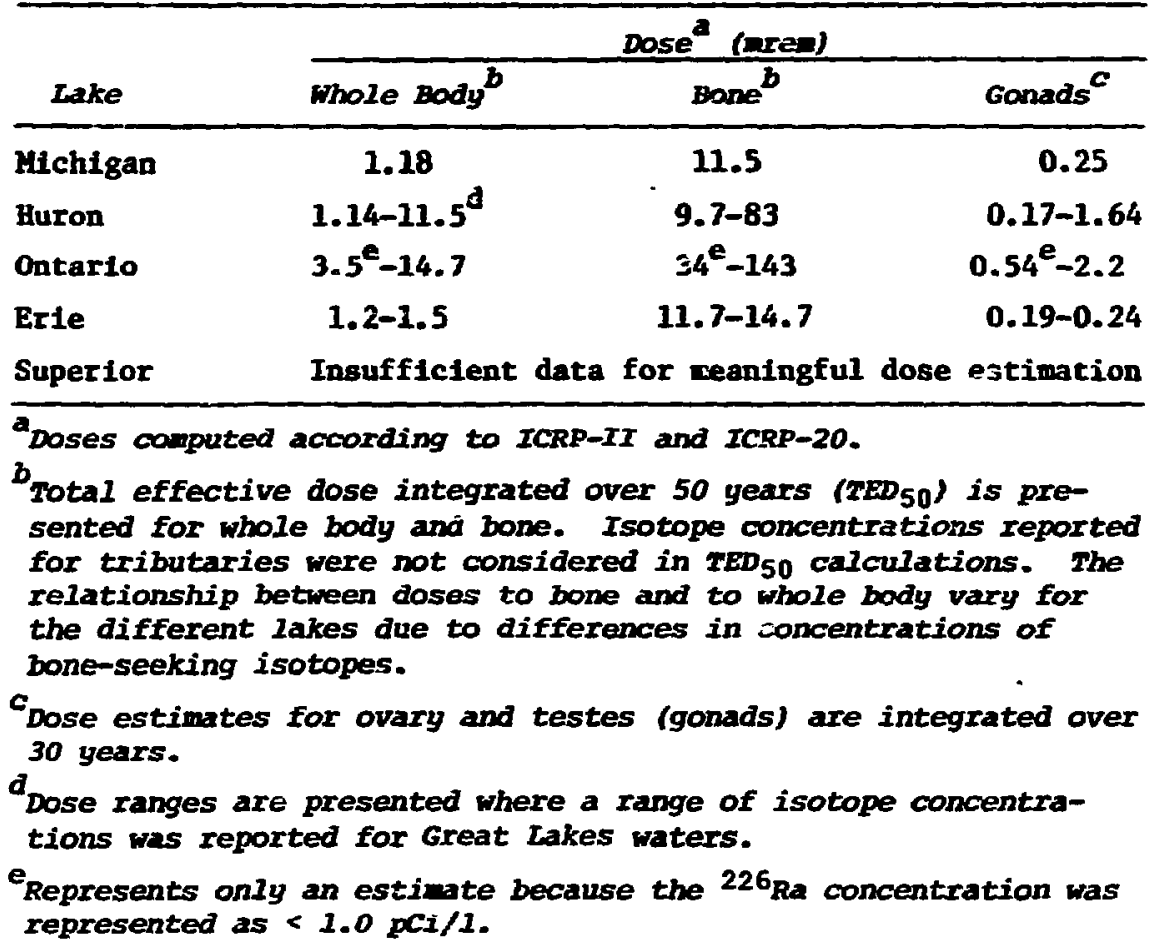

nembers of the general public. The dose lintts for bone are a factor of six higher. Based on this proportion, the TED 50 for bone would be 6 mren when the whole-body objective is a TED 50 of 1 mree. Thus, an objective of 6 mren for bone is exceeded in all the lakes.

\subsection{CONCLUSION}

\subsubsection{TED 50 Estimates Exceed One-MHlliren Objective}

The conclusion from these dose estinates is that TED $_{50}$ values for whole body and bone are currently in excess of the one-nillires objective. The upper-range values for gonads are also in excess of 1 mren for all lakes except Michigan. Thus, adoption of the one-ailliren object1ve, which likely would soon becose a standard, would require extensive "cleanup" of Great Lakes waters. Overall cleanup of Great Lakes waters is technically and economically impractical. However, as pointed out in Section 7 , interceptive measures such as water treatment before Ingestion are feasible. 
Selection of the $\mathrm{TED}_{50}$ criterion is questionable because only one-year ingestion is specified. Becuuse excess risk of carcinogenesis or antagenesis is the endpoint of concern, doses that result from ingestion of water for some period longer than one year, e.8. 30-50 years, should be considered for a conservative estimate of health effects.

\subsubsection{Comparison of TED 50 Estimates after One Year and 50 Years of Water Ingestion}

Doses to whole body and bone that result from 50 years of water ingestion are compared with doses after one-year ingestion in Tables 6-9. Total accumulated doses to gonads are compared for a 30-year reproductive period following water ingestion for either one year or 30 years. Whole-body and bone doses, integrated over 50 years after ingesting water fron the Great Lakes for 50 years, exceed the TED 50 estimates by factors of $\sim 40-50$. Gonadal doses after 30 years of water consunption exceed the dose following one-year consumption by factors of $n 20-25$. If the dose after 50 years of mater consumption 18 accepted as more relevant to prediction of deleterious effects of radiation, note should be taken of upper-linit estimates of $41-498 \mathrm{mrem}$ for whole body, 2800-4900 mren for bone, and 6-50 mren for gonads after consumption of water fron Lakes Huron, Ontario, and Erie for 50 years. Values for Lake Michigan water consumption are appreciably lower due to the $226_{\mathrm{Ra}}$ concentration reported (Tables 2 and 4 ).

Table 6. TED 50 from Radionuclides Heasured in Lake Michigan Waters

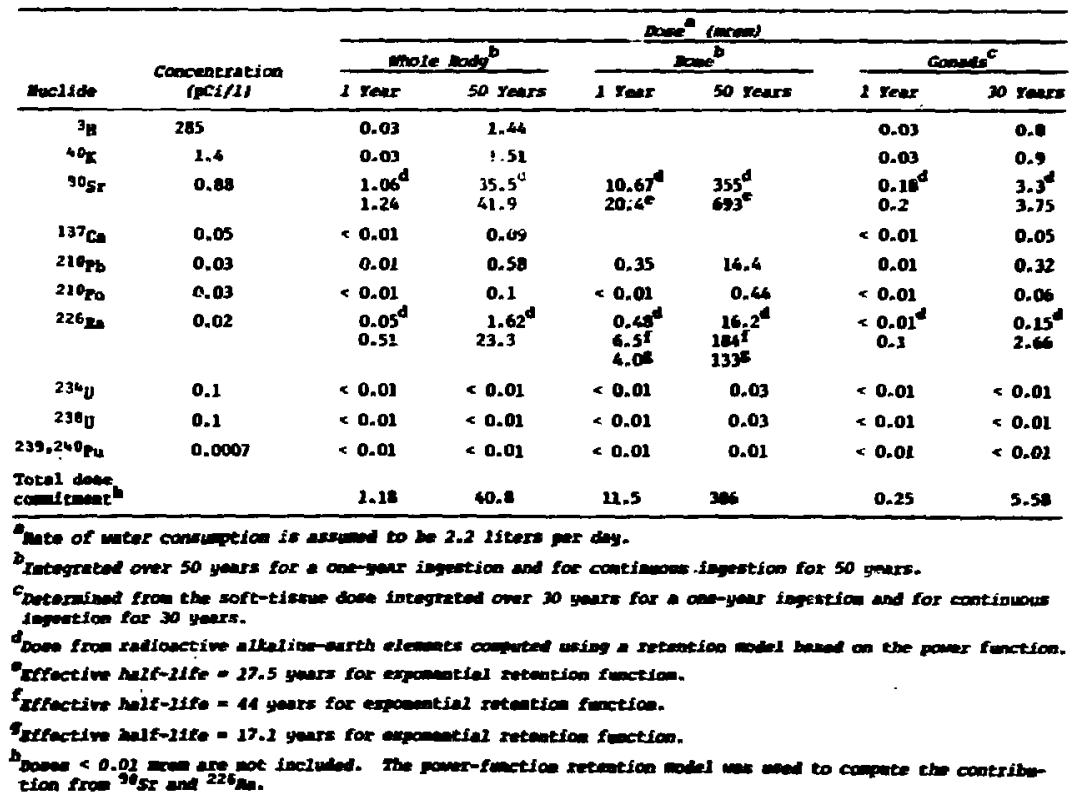


Table 7. TED 50 from Radionuclides Measured in Lake Huron Waters

\begin{tabular}{|c|c|c|c|c|c|c|c|}
\hline \multirow[b]{3}{*}{ Muslide } & \multirow{3}{*}{$\begin{array}{c}\text { Conceatration } \\
\text { (pai/1) }\end{array}$} & \multicolumn{6}{|c|}{ Dosecen } \\
\hline & & \multicolumn{2}{|c|}{ make pody ${ }^{b}$} & \multicolumn{2}{|c|}{ Doseb } & \multicolumn{2}{|c|}{ Coredsts } \\
\hline & & 2 rear & 50 rears & 1 ran & 50 rews & 1 row & 30 Yans \\
\hline $\begin{array}{r}3 \mathrm{H} \\
40_{\mathrm{K}}\end{array}$ & $2,700-30,300$ & $0.17-3.07$ & $9.6-154$ & & & & \\
\hline${ }^{90} \mathrm{st}$ & $0.61-1.07$ & $\begin{array}{l}0.73-1.2^{d} \\
0.86-1.51\end{array}$ & $\begin{array}{l}25-40^{d} \\
29-51\end{array}$ & $\begin{array}{r}7.3-12.0^{\mathrm{d}} \\
14.1-24.7^{\mathrm{e}}\end{array}$ & $\begin{array}{l}246-404^{d} \\
463-759^{e}\end{array}$ & $\begin{array}{l}0.12-0.2^{d} \\
0.16-0.25\end{array}$ & $\begin{array}{l}2.3-6.0^{d} \\
2.6-4.6\end{array}$ \\
\hline $\begin{array}{l}1{ }^{13} 7_{\mathrm{C}} \\
210_{\mathrm{Pb}} \\
210_{\mathrm{Po}}\end{array}$ & $0.024-0.09$ & 0.01 & $0.04-0.16$ & & & & \\
\hline $226 \sqrt{n}$ & $0.1-3.0$ & $\begin{array}{r}0.24-7.2^{d} \\
2.5-75.3\end{array}$ & $\begin{array}{l}8.1-243^{d} \\
117-3,501\end{array}$ & $\begin{array}{c}2.4-71^{4} \\
32.2-971^{f} \\
20.2-605\end{array}$ & $\begin{array}{l}00,9-2,427^{d} \\
921-27,000^{f} \\
66 e-20,000^{x}\end{array}$ & $\underset{0.5-15}{0.05-1.44^{d}}$ & $\begin{array}{r}1.62-49^{d} \\
23-700\end{array}$ \\
\hline $\begin{array}{l}234 \mathrm{u} \\
238_{u}\end{array}$ & & & & & & & \\
\hline $239,240 \mathrm{mu}$ & & & & & & & \\
\hline $\begin{array}{l}\text { Totel dose } \\
\text { colcenes }\end{array}$ & & $1.14-11.5$ & $42-637$ & $9.7-83$ & $327-2,831$ & $0.17-1.64$ & $3.9-53$ \\
\hline
\end{tabular}

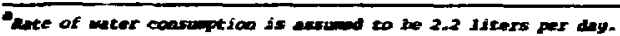

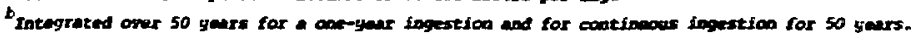

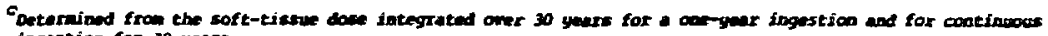
ingertion for 30 yants.

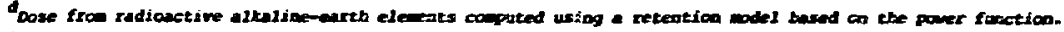

Effective bulf-11fe = 27.5 gars for exponencial retention function.

feffoctive half-life - it yers for exporeatial zetention tuactica.

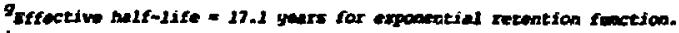

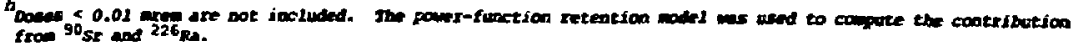

\section{Table 8. TED 50 from Radionuclides Measured in Lake Ontario Waters}

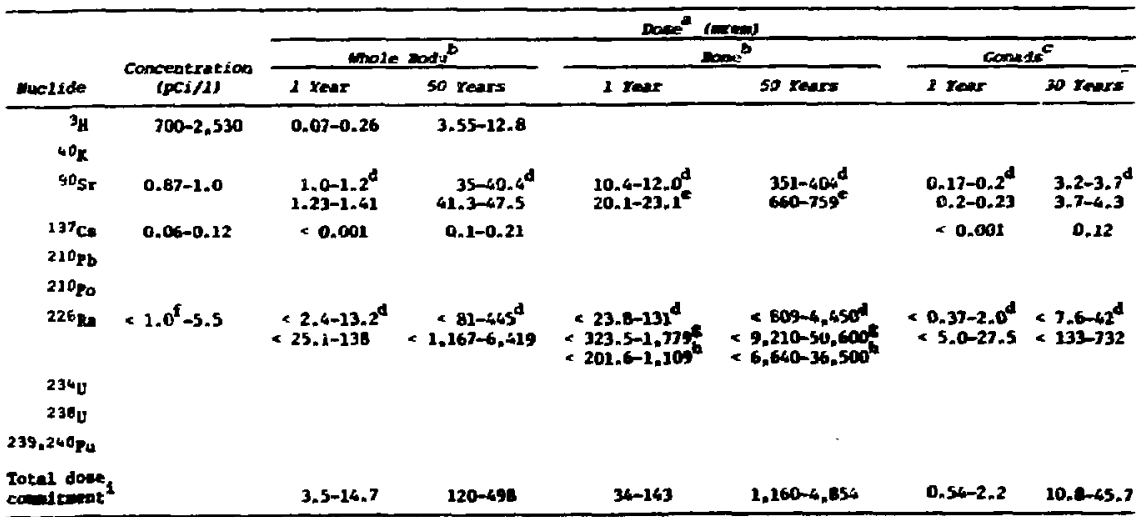

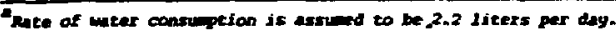

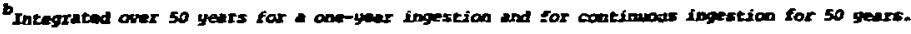

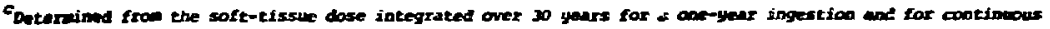
inpurtion for 30 genrs.

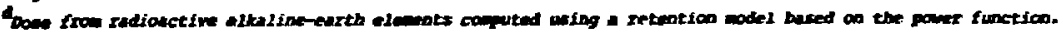

Effectiv belf-life = 17,5 yeurs for exponential retention function.

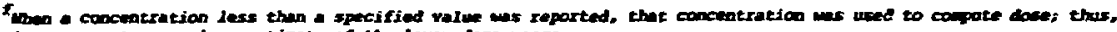

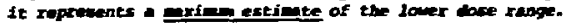

Orfective half-2ife =" 44 yark for exponential retention function.

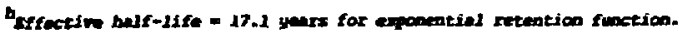

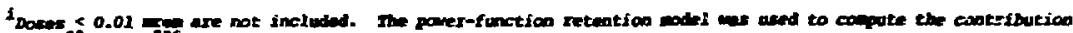
from 90 sr are 220 a. 
Table 9. TED 50 from Radionuclides Heasured in Lake Erie Waters

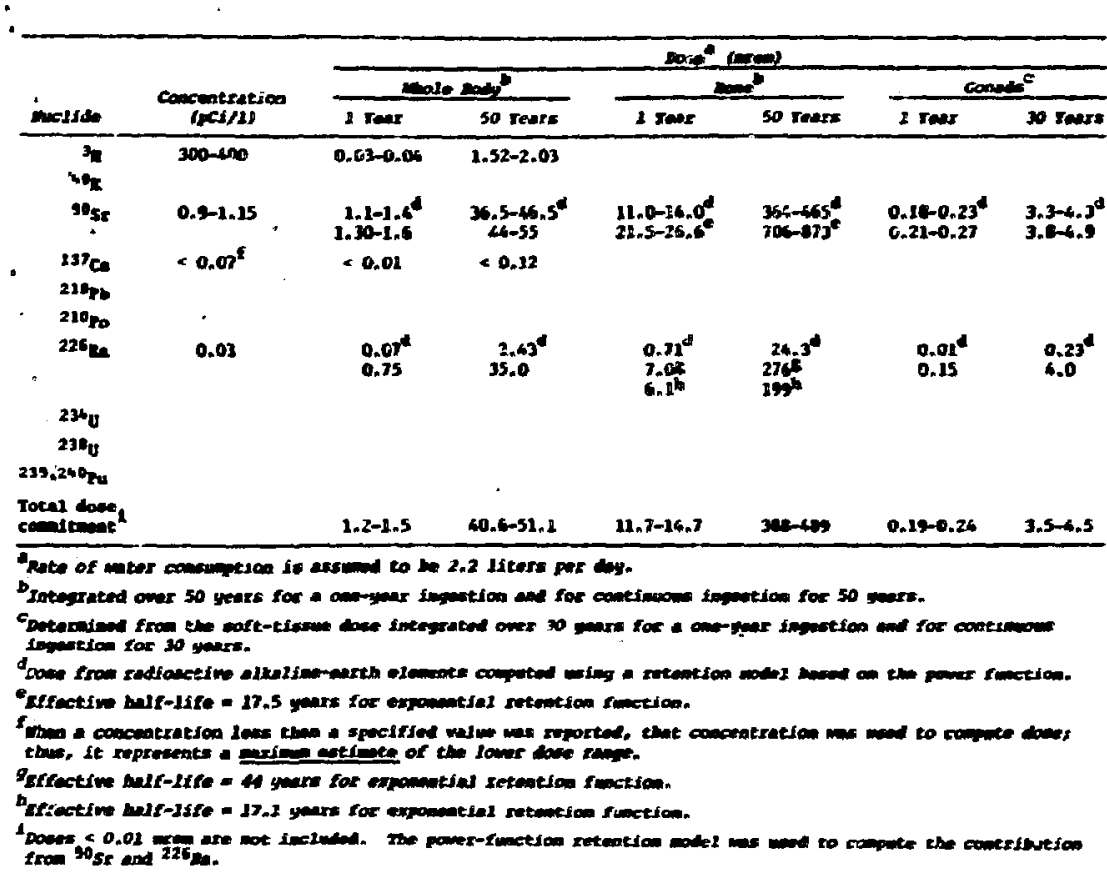

\subsection{DOSE PERSPECTIVES}

The dose conituents cited aboye are high in comparison with the onemillirem objective. Bacikground radiation of $\sim 120$ mrea/yr produces a total dose of 6000 mren in 50 years. The average population dose 1 init of $130 \mathrm{mrem} / \mathrm{yr}$ for genetic and somatic tissues (MCRP-43) produces a total dose of 6500 mrem in 50 years. Table 10 sumarizes the $\mathrm{TD}_{50}$ estinates for maximum permissible concentrations (HPC) of several isotopes of interest. Note especially that the MPC (10 CFR 20) for any single isotope in Table 10 produces a TED 50 greatly in excess of the 1-5 mrem range considered in the water-quality objective.

It is unclear to the Argonne staff why the revised vater-quality objective is one aflliren. Does some basis exist for election of a TED 50 of 1 rather than $0.1,10$, or 100? If MPC levels are considered "safe", or acceptable levels of risk, why were lower values selected?

The dose comitments presented in Table 10 were made by the same procedures used In estination of doses fron lake waters, so whatever the uncertainties about absolute dose calculation, the comparisons between doses from LPC Ievels and the one-milirem objective are valid. Our methods of dose calculation are docusented fully (Table 11 and App. A) to facilitate comparison 
Table 10. TED 50 fron Maximum Permissible Concentrations (MPC) of Radiolsotopes in Water

\begin{tabular}{|c|c|c|c|c|c|c|c|}
\hline \multirow[b]{3}{*}{ Muclide } & \multirow{3}{*}{$\underset{(p<i / 1)}{\operatorname{sac}}$} & \multicolumn{6}{|c|}{ Dome (1real) } \\
\hline & & \multicolumn{2}{|c|}{ roole Dody } & \multicolumn{2}{|c|}{ ene } & \multicolumn{2}{|c|}{ conde ${ }^{c}$} \\
\hline & & 2 rear & so rears: & 1 rear & 50 rans: & 1 reas & 30 rears \\
\hline $3 n$ & $30,000,000$ & 3,000 & 153,000 & & & 3,000 & 91.200 \\
\hline $905 x$ & 300 & $\begin{array}{l}360^{d} \\
420\end{array}$ & $\begin{array}{l}12,100^{d} \\
16.250\end{array}$ & $\begin{array}{l}3,600^{d} \\
6,930^{\circ}\end{array}$ & $\begin{array}{l}120,000^{d} \\
230,000^{e}\end{array}$ & $\begin{array}{l}60^{\circ} \\
70\end{array}$ & $\begin{array}{l}1,710^{d} \\
1,275\end{array}$ \\
\hline${ }^{137} \mathrm{Cs}$ & 20,000 & 700 & 34,600 & & & 700 & 20,600 \\
\hline $210^{\mathrm{Fb}}$ & 100 & 43 & 1.750 & 1.160 & 48,000 & 43 & 1,080 \\
\hline $210_{\mathrm{Po}}$ & 700 & 48.3 & 2,408 & 210 & 10,000 & 48.3 & 1,442 \\
\hline 226 ta & 300 & $71^{d 53}$ & $\begin{array}{c}2,427^{d} \\
35,000\end{array}$ & $\begin{array}{r}724^{4} \\
9.650^{f} \\
6,049^{5}\end{array}$ & $\begin{array}{l}24,300^{d} \\
276,000^{f} \\
200,000^{2}\end{array}$ & 150 & $4.000^{d}$ \\
\hline${ }^{234} \mathrm{U}$ & 30,000 & $\begin{array}{c}0.10^{d} \\
12.45\end{array}$ & $\begin{array}{l}330^{\circ} \\
630\end{array}$ & $201.0^{\circ}$ & $\begin{array}{l}3.300^{\circ} \\
9.900\end{array}$ & $12.45^{d}$ & $360^{d}$ \\
\hline${ }^{236} \mathbf{v}$ & 40,000 & $\begin{array}{c}9.86^{d} \\
14.56\end{array}$ & $\begin{array}{l}400^{d} \\
720\end{array}$ & $\frac{92.8}{228}$ & $\begin{array}{c}4,000^{d} \\
11.200\end{array}$ & $14.56^{d}$ & $480^{\circ}$ \\
\hline $239.260^{\mathrm{Pu}}$ & 5,000 & $\begin{array}{c}350^{d} \\
75\end{array}$ & $\begin{array}{l}8,900^{d} \\
2,000\end{array}$ & $\begin{array}{l}3,500^{d} \\
3,150^{\circ}\end{array}$ & $\begin{array}{l}89,000^{d} \\
82,000\end{array}$ & $3.937 .7^{40}$ & $217,000^{750^{d}}$ \\
\hline
\end{tabular}

Rate of water consulption is assuned to be 2.2 liters per duy.

Integreted over 50 gears for a one-year ingestion and for continoous sogestion for so gears.

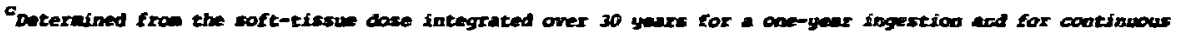
ingestion for 30 yexrs.

dosse fzom radianctive altaline-earti elements computed uriog a retention model baved on the power function.

Effective half-life = $\mathbf{1 7 . 5}$ gnars for exponential retention function.

Effective half-life - 14 years fox exponential retention function.

giffective belf-1ife = 17.1 gars for exponentila retention function.

\section{Table 11. TED 50 from a Radionuclide concentration of One Picocurte per Liter}

\begin{tabular}{|c|c|c|c|c|c|c|}
\hline \multirow[b]{3}{*}{ Muelide } & \multicolumn{6}{|c|}{$D=e^{\circ}$ (ard } \\
\hline & \multicolumn{2}{|c|}{ mole cody ${ }^{b}$} & \multicolumn{2}{|c|}{ cans } & \multicolumn{2}{|c|}{ Conadse } \\
\hline & 1 Youse & so rears & 2 rour & 50 rears & 1 rear & 30 rears \\
\hline${ }^{3} \mathbf{y}$ & 0.0001 & 0.0051 & & & 0.0001 & 0.00306 \\
\hline${ }^{40} \mathrm{x}$ & 0.02 & 1.08 & & & 0.02 & 0.69 \\
\hline${ }^{90} \mathrm{sr}$ & $\begin{array}{l}1.22^{\mathrm{d}} \\
1.4^{\circ}\end{array}$ & $\begin{array}{l}40.4^{d} \\
47.5^{-1}\end{array}$ & $\begin{array}{l}12.0^{\mathrm{d}} \\
23.1^{\mathrm{e}}\end{array}$ & $\begin{array}{l}400^{d} \\
759^{6}\end{array}$ & $\begin{array}{l}0.20^{d} \\
0.23\end{array}$ & $\begin{array}{l}3.7^{d} \\
4.26\end{array}$ \\
\hline${ }^{137} \mathrm{Cs}$ & 0.035 & 1.73 & & & 0.035 & 1.03 \\
\hline $210_{P b}$ & 0.43 & 19.3 & 11.8 & 480 & 0.43 & 10.8 \\
\hline 2265 & $25.4^{d}$ & $1,167.9^{d d}$ & $\begin{array}{r}23.8^{\mathrm{d}} \\
232.5^{\mathrm{f}} \\
201.6^{\mathrm{E}}\end{array}$ & $\begin{array}{c}2000^{4} \\
9,210^{K} \\
6,640^{6}\end{array}$ & $\begin{array}{l}0.37^{d} \\
5.0\end{array}$ & $133^{7.6^{d}}$ \\
\hline $234 \mathrm{U}$ & $\begin{array}{l}0.000270^{d} \\
0.000415\end{array}$ & $\begin{array}{l}0.011^{d} \\
0.021\end{array}$ & $\begin{array}{l}0.0027^{d} \\
0.0067\end{array}$ & $\begin{array}{l}0.11^{d} \\
0.33\end{array}$ & $0.000415^{d}$ & $0.012^{d}$ \\
\hline $23 \theta_{y}$ & $\begin{array}{l}0.000247^{d} \\
0.000366\end{array}$ & $\begin{array}{l}0.010^{d} \\
0.018\end{array}$ & ${ }_{0.0021^{d}}^{0.0057}$ & $\begin{array}{l}0.10^{d} \\
0.28\end{array}$ & $0,000364^{d}$ & C.o11 ${ }^{d}$ \\
\hline $239.240 \mathrm{Pu}$ & $\begin{array}{l}0.07^{d} \\
0.015\end{array}$ & $1.28^{d}$ & $\begin{array}{l}0.7^{d} \\
0.63\end{array}$ & $\begin{array}{l}17.8^{d} \\
16.4^{-1}\end{array}$ & $0.0095^{d}$ & $0.25^{d}$ \\
\hline
\end{tabular}

Cinte of wer contuption is assuned to be 2.2 zieers per 4 y.

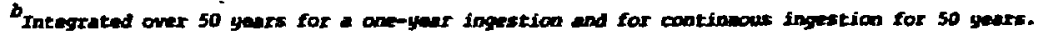

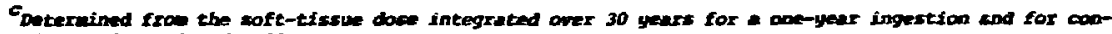
tinuous ingestion for 30 yours.

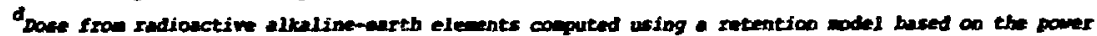
function.

Effective half-2ife = 17.5 years for exponential retention function.

Iffective half-life - 14 genrs for exponentill retention fonction.

Iffective half-iffe = 17.1 gens: for exponential netention fooction. 
of dose estimates provided here with dose estinates of others. Unfortunately, we have been unable so far to locate a complete description of procedures used to calculate $\mathrm{TED}_{50}$ by the Radioactivity Subcomittee of the Great Lakes Water Quality Board.

\section{COST-BENEFIT CONSIDERATIONS}

\subsection{INTRODUCTION}

\subsubsection{Scope of Considerations}

This section describes the Argonne staff's preliminary considerations of three 1ssues:

(1) health effects resulting from ingestion of the radionuclides reported to be in the Great Lakes,

(2) the cost of reducing the concentralions of radionuclides from Great Lakes water that is ingested, and

(3) the annual dollar anount American citizens wight be villing to pay to reduce the health effects resulting from ingestion of the radionuclides believed to be in the Great Lakes.

The staff also wishes to call attention to the following pertinent issues not treated in this report:

(1) the number of people sho are ingesting water from the Great Lakes,

(2) the 1ikelihood that others will ingest water from the Great Lakes,

(3) the value of reducing concentrations only on the chance that water for ingestion might be drawn from the Great Lakes,

(4) the possibility tha: the money spent on reducing the radionuclide concentration in water drawn from the Great Lakes could be more visely spent elsewhere,

(5) the possibility that radionuclides will adversely affect biota other than man or accumlate in the food chain, and

(6) the possibility of eliminating or retarding other beneficial uses of the Great Lakes due to unnecessarily stringent water-quality objectives and standards.

\subsubsection{Organization}

The following sections describe the staff"s considerations of the three issues cited in Section 6.1.1. Section 6.2 reviews the principal health effects to be expected from ingesting the concentrations of radionuclides reported to be in the water of the Great Lakes. Section 6.3 describes ways to assign a dollar value to the reduction of these health effects. Section? 
estimates the feasibility and dollar cost of reducing the concentration of radionuclides in drinking water drawn from the Great lakes.

\subsection{HEALTH EFFECTS \\ 6.2.1 Introduction}

Our discussion concerns the possible harm from ingestion of the radionuclides (Sec. 6.2.2), the probability of harm (risk) per dose (Sec. 6.2.3), and the expected dose per isotope concentration (Sec. 6.2.4).

\subsubsection{The Possible Harns}

The radionuclides that we helieve to be the principal sources of activity in the Great Lakes are ${ }^{3} \mathrm{H},{ }^{226} \mathrm{Ra}$, and ${ }^{90} \mathrm{Sr}$. After ingestion, ${ }^{3} \mathrm{H}$ is the source of a smaller dose than either ${ }^{226} \mathrm{Ra}$ or ${ }^{90} \mathrm{Sr}$ (Table 11). The radiological consequences of current and projected ${ }^{3}$ if concentrations in the Great Lakes are considered insignificant. ${ }^{6}$ Most ${ }^{226} \mathrm{Ra}$ and ${ }^{90} \mathrm{Sr}$ retained by the body is incorporated in bone. Because of this, we believe that the principal somatic hare that could result from ingestion is bone cancer and leukenia.

A different possible harn is that done to our descendants because of our exposure to Ionizing radiation. Although no clinical evidence of such a result is known for humans, laboratory studies of drosophila and nice have led to the belief that lonizing radiation can induce chowosonal and genetic change in humans that wil result in some damaged descendants. Because the relationship between radiation-induced mutations and resulting darage is unknown, we and others assume that the nature of the damage to offspring is independent of the mutagenic agent. These results have great variety and range from polydactyl effects to Huntington"s chorea. These genetic effects may be expressed many generations after the ancestor's exposure.

\subsubsection{The Probability of Harn per Dose}

Although there is widespread agreement that cancers may be induced by ionizing radiation, there are no data from which one can unambiguously infer the probability of the incidence of various cancers induced in wan from sall doses delivered at 10 rates. Thus we assume, as do others, that risk depends only on the dose and not on the dose rate. Note that the weasure of dose, the unit of which is the ren, is itself not entirely free of anbiguity because it is the product of the energy deposited per mass of tissue and a factor called the "relative biological effectiveness", which is sonetimes determined after the fact. Our subject is beset by these uncertainties because the low probability of harm can be isolated from other factors only by studying wuch larger populations for wch longer tines than has heretofore been possible. In the following paragraphs we sumarize the findings of the BEIR Report (Chapter 7) on the relation of ionizing radiation to the risk of leukenia, bone cancer, and genetic damage. 


\section{Leukemia}

The principal sources of data for adults come fron the study of spondylitis patients, females clinically sterilized with $X$ rays, and atontc-bonb casualties. The conclusion is that the data are compatible vith a direct proportion between dose and risk. For persons over the age of ten the dose Is followed by a latent period of several years and then an elevated risk of leukemia of $1-2 \times 10^{-6}$ per year per rem. For children under ten years ti age the elevated risk is in the range $1.6-3.4 \times 10^{-6}$ per year per rem, wereas for exposure in utero the elevated risk is $27 \times 10^{-6}$ per year per rem.

\section{Bone Cancer}

The principal sources of data come from studies of persons who have ingested ${ }^{226} \mathrm{Ra}$ and of spondylitis patients. There is some evidence that by assuming a direct proportion between dose and risk one overestimates the real rlsk from sinall doses. We prefer to err on the side of safety. Assuning a direct proportion, the data on persons over 20 years of age gives an elevated risk of $0.10-0.55 \times 10^{-6}$ per year per rea, and for persons under 20 years the elevated risk is $0.96 \times 10^{-6}$ per year per rem.

\section{Genetic Darage}

Because the foregoing estimates of risk are imperfectly known, the staff is In a fundamentally nore speculative area when it tries to estinate the damage to future generations from the present generation"s exposure to ionizing radiation. Any such estimate mist be based on experimental work with drosophila and nice together with educated guesses on the relation of this work to humans. We have adopted the BEIR Report estinate of $60-1500 \times 10^{-6}$ damaged descendants per ancestor-ren, of which 12-200 $\times 10^{-6}$ occur in the first generaiion.

\subsubsection{Dose per Concentration}

In Section 4, our knowledge of the concentrations of various radionuclides in each of the Great Lakes is revieved. Table 4 displays these concentrations (pCI/1), and Tables 5-9 present our estimates of the resulting dose (mren) to the whole body, bone, and gonads. Two features of Tables 5-9 nust be explained. First, the whole-body dose is less than the bone dose. This is because dose depends on where in the body energy is deposited. Because the radionuclides in question are incorporated in bone, and because the whole body is larger than the skeleton, the skeletal or bone dose is higher. Second, the total dose at the end of 50 years, after ingesting lake water for one year, is nore than one-fiftieth of the total dose received from ingesting lake water for 50 year6, i.e. 50 tines the TED 50 for one-year ingestion is higher than the TED 50 for 50-year ingestion. This is because the dose is prorated over a long period of tine after fsotope ingestion. Thus, the risk from drinking Great Lakes rater depends on the number of years that a person has already drunk water. Such an analysfis would show that the risk per year increases over the adult lifetive of each person. 
We overestimate the annual somatic risk by assuming that it has the same value for each year of adulthood, and that this value is the same as the annual risk after 50 years of ingestion at the rate of 2.2 liters/day. The 50-year bone dose per pCi/1 from ${ }^{226} \mathrm{Ra}$ is 0.81 rem. The 20- and 10-year doses per are pC1/1 are 0.208 ren and 0.074 ren, respectively. We also overestimate the bone dose to a child in utero by using the one-year bone dose to an adult, which 180.002 ren per $\mathrm{pCl} / 1$. To estinate the genetic and chromosomal dawage, we assune that the dose to the gonads resulting from 30 years of ingestion is relevant. This is estimated to be 0.0076 rea per pCi/1.

\subsection{THE VALUE OF RISK REDUCTIOA}

\subsubsection{Introduction}

Although the previous section describes the risk of deleterious health effects, this Information is not sufficient for a discussion of the costs and benefits of the proposed standard. After all, virtually everyone occasionally submits himself to greater risk by driving fast on slippery roads, and sone people smoke cigarettes willingly. A pair of fundamental questions are, "Do people wish to reduce their risk?" and, if so, "How much would these people willingly pay to reduce their risk?" These are not the only fundamental questions because the risk also falls on children and the unborn. Because it is widely held that parents are responsible for the protection of their children, the appropriate question is, "Bow much would a parent pay to reduce a risk to his or her child?" Although parents accept the responsibility for their children's protection, no flat statewent can be made for parents' attitudes toward their more remote descendants. Thus, we nust ask, "What is the present generation's responsibility to future generations?"

We assume that people would like to reduce the risk to thenselves caused by ingestion of radionuclides in water because we are unaware of any pleasure concomitant with ingestion such as occurs with cigarettes or alcohol. We also assume that people would willingly pay something to reduce their risk. "How much" is discussed in Section 6.3.3. We further assume that parents would pay at least as much to protect their children as to protect themselves.

The question, "What is the present generation's responsibility to future generations?" is difficult to answer. The staff does not believe nost people would feel obliged to reduce the concentrations of radionuclides in the Great Lakes below those found at the time of their ow birth. If this generation accepts a respongibility for the effects of what it has added to the Great Lakes, it must ask how it afght discharge this responsibility. As an alternative to simply cleaning up, we aght establish a fund out of wich our genetically defective descendants would be compensated. If the size of the fund is sufficient to compensate all of our danaged descendants who could hold this generation liable (between 60 and $1500 \times 10^{-6}$ per ancestor-rem), we must decide on the size of the comensation. Because some genetic defects can incapacitate a person, we aght overestimate the compensation by giving each damaged descendant a iifetime stipend equivalent to the median lifetine - earnings of this generation. 


\subsubsection{Relation of Rigk to Earnings}

Unfortunately, there are fed transactions in which the purchase of safety can be distinguished by analysis from other components of the exchange (e.g. choice of car type or howe). However, there is some evidence that as occupational risk increases, so do wages. He belleve this broad trend is not accidental and that it provides a rough Indication of the increnental pay that w1I Induce some persons to bear an increnental fisk or, conversely, it provides a rough indication of the lower linit of the incremental wage most people would sillingly forgo to avold a risky job. In the following paragraphs, we sumarize the results of three different efforts to study the relation of job risk to wages.

Thaler and Rosen? studied the relation between wages and wortality by occupation for a population of $\mathbf{9 0 0}$ adult-male heads of households froa data collected from the 1967 Current Population Survey. The mean age vas 41.8 years, the wean nuber of years of schooling was 10.11, and the wean weekly wage was $\$ 132.65$ [\$132.65 (1967 dollars) - \$224.45 (1976 do11ars)]. Each of the nembers of the sample worked in one of 37 occupations, the nembers of which had a nortality rate that was significantly higher than the population at large. After controlling for other variables, Thaler and Rosen concluded that the incremental annual vage per incremental anoual risk of death was:

$$
\frac{\$ 200 \pm 60(1967 \text { dollars }) / \mathrm{xx}}{10^{-3} \text { risk of death/yr }}
$$

which is:

$$
\frac{\$ 338.41 \pm 101.52(1976 \text { dollars }) / x x}{10^{-3} \text { risk of death/yx }}
$$

Because the sample members had less-than-average earnings we find it plausible that the woney they would forgo for risk reduction is less than the population at large vould forgo. In other words, we find it plausible that the general population would spend pore for risk reduction than would the sample because the general population is wealthier than the sample.

Snith ${ }^{8,9}$ studied the relation between wages and injuries sustained on the job for hourly vorkers in three-digit manufacturing industries. He found that a risk reduction from $16 \times 10^{-5}$ death/gr to $8 \times 10^{-5}$ death/gr resulted in a decrease of 1.57 in annual wage. Because the average wage in his sasple was $\$ 8000$ (1973 dollars), one can infer that the incremental annual wage per incremental annual risk for his sample vas:

$$
\frac{\$ 120(1973 \text { dollars }) / \mathrm{sr}}{8 \times 10^{-5} \text { risk of death/yr }}
$$

which is:

$\frac{\$ 153.00(1976 \text { dollars }) / y x}{8 \times 10^{-5} \text { rist of death/yx }}$ 
Viscuzzi 10 also studied the relation between wages and injuries resulting in death that were sustained on the job for a sample of 496 blue-collar workers whose average annual incose in 1969 was $\$ 6809.90$ (1969 dollars). The range of risk for these industries is between zero and $10^{-4}$ death/yr. He fitted his data in several ways. After controlling for other variables, including whether or not the vorker judged his job to be dangerous, Viscuzzi found a range from $\$ 0.48 \times 10^{6}$ to $\$ 168 \times 10^{6}$ (1969 dollars) or:

\section{$\$ 16.65 \pm 9.25$ (1976 dollars)/yx $10^{-5}$ risk of death/yr}

The results (rounded to three significant figures) of these three studies of the labor market are:

\begin{tabular}{lc}
\multicolumn{1}{c}{ Study } & $\frac{\$(1976 \text { dollars }) / y x}{10^{-6} \text { risk of death/yr }}$ \\
\hline Thaler and Rosen & \\
Smith $^{8}, 9$ & 0.34 \\
Viscuzz1 $^{10}$ & 1.91 \\
& 1.67
\end{tabular}

Each of these figures was reached by studying samples with less-than-average earnings. Thus, we expect the general population to be willing to spend more than these anounts to reduce their own risk.

\subsubsection{The Value of Reducing the Concentration of ${ }^{226}$ Radium in Drinking Water}

In this section, we roughly estimate the anount of money the population would be willing to spend to reduce the concentration of $22 \sigma_{\mathrm{Ra}}$ in its drinking water. Let us suppose the typical adult would pay the sane annual tax to reduce the risk of harn from ${ }^{226} \mathrm{Ra}$ as he would to reduce the risk of death. The annual tax is the product of three factors. The first factor is the risk-avoidance premiun discussed in Section 6.3.2, which we believe is greater than $\$ 1.9 \times 10^{6} / y x$ per risk of death/yr. The second factor is the risk of leukemia and bone cancer per year per dose, which was discussed in Section 6.2.3. The third factor is the dose per concentration, which was discussed in Section 6.2.4. The product of the three factors is:

$$
\frac{\$ 1.9 \times 10^{6} / \mathrm{yr}}{\mathrm{risk} / \mathrm{yr}} \times\left[(1.1-2.6) \times 10^{-6} \frac{\mathrm{risk} / \mathrm{yr}}{\mathrm{rem}}\right] \times\left[0.810 \frac{\mathrm{rem}}{\mathrm{pCI} / 1}\right]
$$

which Is:

$$
\frac{\$ 1.69 \text { to } 4.00 / \mathrm{yr}}{\mathrm{pCi} / 1}
$$

We also suppose that adults will pay as much to protect each of their children as to protect themselves. If half the adults have two children under 
20 years of age, the amount spent to protect the child from bone cancer would be:

$$
\frac{\$ 2 \times 0.5 \times 1.9 \times 10^{6} / \mathrm{yr}}{\mathrm{risk} / \mathrm{yr}} \times\left[0.96 \times 10^{-6} \frac{\mathrm{risk} / \mathrm{yr}}{\mathrm{ren}}\right] \times\left[0.208 \frac{\mathrm{rem}}{\mathrm{pCi} / 1}\right]
$$

If one-quarter of the adults have two children under 10 years of age, the amount spent to protect the child from leukemia would be:

$$
\frac{\$ 2 \times 0.25 \times 1.9 \times 10^{6} / \mathrm{yr}}{\mathrm{risk} / \mathrm{yr}} \times\left[(1.6-3.4) \times 10^{-6} \frac{\mathrm{risk} / \mathrm{yr}}{\mathrm{rem}}\right] \times\left[0.074 \frac{\mathrm{ren}}{\mathrm{pCi} / 1}\right]
$$

If one-fiftieth of the adults have a child in utero, the amount spent for protection from leukemia would be:

$$
\frac{\$ 0.02 \times 1.9 \times 10^{6} / \mathrm{yr}}{\mathrm{risk} / \mathrm{yr}} \times\left[27 \times 10^{-6} \frac{\mathrm{risk} / \mathrm{yr}}{\mathrm{ren}}\right] \times\left[0.002 \frac{\mathrm{rem}}{\mathrm{pCi} / 1}\right]
$$

The total to protect the average adult and his or her children is in the range of:

$$
\frac{\$ 2.18 \text { to } 4.62 / \mathrm{yx}}{\mathrm{pCi} / \mathrm{I}}
$$

We stress that this can only be regarded as a rough estimate of what the taxpaying population might pay per capita for reduction in the concentration of ${ }^{226} \mathrm{Ra}$ in its drinking water. The roughness of the estimate stens from at least three sources. First, the risk premium has been inferred from the labor market and may be an underestimate. Second, the risk per dose is imperfectly known and may be an overestimate. Third, the dose per concentration is an overestimate because we have basically assumed that the cumulative dose is delivered at the beginuing of the relevant period.

We might also consider the relation between the concentration of ${ }^{226} \mathrm{Ra}$ in our water and the number of damaged descendants. In Section 6.2.3, we quoted the range 60-1500 $\times 10^{-6}$ danaged descendants per ancestor-rew and in Section 6.2.4 we found that the 30-year dose per concentration to gonads from ${ }^{226} \mathrm{Ra}$ was $0.0076 \mathrm{rem}$ per $\mathrm{pCi} / 1$. This yields $0.46-11.4 \times 10^{-6}$ damaged descendants per pCi/1 to this generation. The fundanental question to which we do not know the answer is, "How much ${ }^{226} \mathrm{Ra}$ did the present generation put in the Great Lakes?"

\section{STRATEGIES ON CLEANUP}

The staff has not identified a means of cleaning up the lakes by rewoving radioactive elements. The focus of the effort has been shifted to strategies to remove man-nade inputs of radioactive elements to the 1akes, and how water may be intercepted for that purpose before consumption.

Even the reduction of man-made inputs to the lakes has a cenuous relationship to the one-millirem TED 50 objective as it is now stated. This relationship breaks dom because: (1) the relative contribution of radioactive sources is not known quantitatively; (2) nost of the ${ }^{226} \mathrm{Ra}$ in the 
lakes is naturally occurring; and (3) although input sources may be treated to reduce radioactivity, it is not likely that changes in radioactivity levels w11 be detectabie.

Two different approaches are examined in light of attaining a onemillirem objective. Whatever nondegradation is worth, the alternatives are to: (1) elininate input to the lakes and (2) remove radioactivity from water after it is withdrawn from a lake and before ingestion by man.

\subsection{INPUT SOURCES AND CLEAMUP EMPHASIS}

The principal dose contributors to man from lake radioactivity are: (1) naturally occurring ${ }^{226} \mathrm{Ra}$ and (2) ${ }^{90} \mathrm{Sr}$ fallout. A few other sources, releases from which may be reduced, have been identified. They are: (1) medical and research facilities, (2) nuclear power plants, (3) runoff from phosphate fertilizer, (4) urantu milling in the Elliot lake (Ontario) area near Lake Huron, and (5) coal-combustion products. (Examination of coal combustion has indicated uranium in slag and combustion products on the order of 0 to $20 \mathrm{ppm} .11$ Theoretically, leaching from slag heaps could represent a pathway to Great Lakes water.) Nuclear power plants contribute to radioactivity through discharge of ${ }^{3} \mathrm{H},{ }^{137} \mathrm{Cs}$, and ${ }^{90} \mathrm{Sr}$ isotopes, but they are not contributors to the ${ }^{226} \mathrm{Ra}$ activity. Accordingly, control of these facilities would not be a part of a "cleanup" strategy that would reduce TED50 sigrificantly.

However, other sources (e g. ${ }^{3} \mathrm{H},{ }^{134} \mathrm{Cs}$, and ${ }^{90} \mathrm{Sr}$ ) are important if the radioactivity objective is shifted froi "in-lake" values to an "as-10w-aspracticable" objective for radionuclides other than ${ }^{226} \mathrm{Ra}$. As far as $226_{\mathrm{Ka}}$ is concerned, only the runoff due to uranium mining and the use of phosphate fertilizer are considered further.

\subsection{ESTIMATE OF ${ }^{226}$ RADIUM INPUT FROM FERTILIZER AND PHOSPHATE PRODUCTS}

Probable but unmeasured sources of ${ }^{226} \mathrm{Ra}$ to the lakes are the fertilizers used within the basin, which then run into the lakes. Harvested cropland areas in the Great Lakes basin represent about $6 \%$ of the U.S. cropland area.12,13 However, there is evidence from trace-element studies that many of these elements are retained in the soil and do not contaminate groundwater or surface water.14 An estimate of phosphorus loss, which may or may not be comensurate with ${ }^{226} \mathrm{Ra}$ loss, is 0.4 lb/acre. 15,16 If $226 \mathrm{Ra}$ is preferentially adsorbed by soil, then the proportional loss of ${ }^{226_{\mathrm{Ra}}}$ in fertilizer would be less than the proportional loss of phosphate.

Another estimate puts annual phosphor:1s eroded from farms at 1800 million pounds.17 This might indicate an annual loss of 48 million pounds to the Great Lakes assuming application rates are constant across producing agricultural cropland6. Estinates of $226 \mathrm{Ra}$ content fron normal superphosphate (Table 12) show a level of $2.3 \times 10^{7} \mathrm{pCi} / \mathrm{ton}$ of fertilizer from the wet process (assuming $50 \% \mathrm{P}_{2} \mathrm{O}_{5}$ content). 18 If the ${ }^{226_{\mathrm{Ra}} \text { content in fertilizer is }}$ multiplied by the loss to the basin, about $552 \mathrm{mCi}$ are distributed annually to the lakes. Again, this assunes that ${ }^{226} \mathrm{Ra}$ is lost at the same rate as phosphorus. 
Table 12. Estimated ${ }^{226}$ Radium, Uranium, and Thorium Activity

in Phosphate Fertilizer Products and By-Products

Based on 1973 Wet-Process Production Dataa (pCi/ton)

\begin{tabular}{|c|c|c|c|c|c|c|c|c|}
\hline Materfal & 226 Ra & & Uranium & & & tho & Din & \\
\hline $\begin{array}{l}\text { sotaperphosphate } \\
\text { superph }\end{array}$ & $2.3 \times 10^{7}$ & b & $\mathbf{b}$ & b & b & b & b & $\mathbf{b}$ \\
\hline $\begin{array}{l}\text { Triple } \\
\text { superphosphate }\end{array}$ & $1.9 \times 10^{7}$ & $5.1 \times 10^{7}$ & $2.5 \times 10^{6}$ & $5.1 \times 10^{7}$ & $1.1 \times 10^{6}$ & $6.1 \times 10^{5}$ & $4.3 \times 10^{7}$ & $3.5 \times 10^{5}$ \\
\hline $\begin{array}{l}\text { Alontum } \\
\text { phosphaces }\end{array}$ & $5.2 \times 10^{6}$ & $5.7 \times 10^{7}$ & $2.8 \times 10^{6}$ & $5.7 \times 10^{7}$ & $1.4 \times 10^{6}$ & $7.2 * 10^{5}$ & $5.9 \times 10^{7}$ & $3.6 \times 10^{5}$ \\
\hline $\begin{array}{l}\text { Phosphoric } \\
\text { ac1dc }\end{array}$ & $5 \times 10^{5}$ & b & $\mathbf{b}$ & $\mathbf{b}$ & b & $\cdot \quad \mathbf{b}$ & $\mathbf{b}$ & b \\
\hline Gypstr: & $3 \times 10^{7}$ & $5.5 \times 10^{6}$ & $2.9 \times 10^{5}$ & $5.5 \times 10^{6}$ & $9.7 \times 10^{5}$ & $1.3 \times 10^{6}$ & $1.2 \times 10^{7}$ & $2.4 \times 10^{5}$ \\
\hline Antalal feed & $5 \times 10^{6}$ & b & $\mathbf{b}$ & $b$ & b & b & $\mathbf{b}$ & $\mathbf{b}$ \\
\hline
\end{tabular}

Taking the annual fertilizer-loss estimate of $0.41 \mathrm{~b} / \mathrm{acre},{ }^{226} \mathrm{Ra}$ loss (proportional to phosphorus) can be estimated in another manner. Haking the conservative assumption that all fertilizer is superphosphate, the basin has 20.7 million acres of productive cropland that would then lose 5.2 willion pounds annually. At $2.3 \times 10^{7} \mathrm{pCi} / \mathrm{ton}$, only $60 \mathrm{mCl} / \mathrm{yr}$ are lost.

A third estimate indicates that phosphorus input to Lake Michigan from erosion is 3.33 million pounds or, because Lake Michigan represents $43 \%$ of the drainage basin, 7.74 million pounds for all the Great Lakes. 19 Using the same ${ }^{226} \mathrm{Ra}$ content as above, $90 \mathrm{mCl} / \mathrm{yr}$ are lost. Regardless of how much phosphorus as fertilizer ultimately reaches the Great Lakes, much depends on whether the ${ }^{226} \mathrm{Ra}$ is eroded at the same rate, on the fertilizer application rates in the basin, and on the kinds of fertilizers applied.

Assuming the Great Lakes now contain 500 curies of $226_{\mathrm{Ra}}$ in the water (and assuming, for illustration, that all the ${ }^{226} \mathrm{Ra}$ from fertilizer mixes with the water colum rather than settles to the bottom) then the highest estimate yields an annual added ${ }^{226} \mathrm{Ra}$ contribution to the lakes from fertilizer of $0.1 \%$ * With these assumptions it would take about 1000 years for the ${ }^{226} \mathrm{Ra}$ content from fertilizer in the lakes to double, assuming no dilution from lake flushing. If it were assumed that inshore areas received ten times the input of $226_{\mathrm{Ra}}$ as the rest of the lakes, it would take about one million years for shore areas to reach the maximum permissible concentration from the addition of fertilizer alone.

* Based on $0.02 \mathrm{pCI} / 1$, which is the average for Lake Michigan. 
Higher existing levels of ${ }^{226} \mathrm{Ra}$ in the Great Lakes other than Lake Michigan do not increase the relative significance of fertilizer as a source. With these higher levels, the time span is shorter before the maximum permissible concentration is reached. Thus, the importance of fertilizer depends on how the objective is expressed rather than on the slow rate of change of radioactivity levels.

\subsection{REMOVAL OF ${ }^{226}$ RADIUM FROM PHOSPHATE AND URANIUM PRODUCTS}

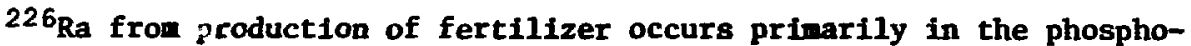
gypsum (about $80 \%$ ) rather than in the $\mathrm{P}_{2} \mathrm{O}_{5}$ acid anhydride used to make phosphate fertilizer. 18 Experience in the uranium-mining and milling industry, water-treatment technology, and phosphate-product industry, indicates a common set of technologies to rewove elements such as ${ }^{226} \mathrm{Ra}$. In the uranium and phosphate industries ${ }^{226} \mathrm{Ra}$ is usually associated with the waste products, or tailings, as a result of the solubilization of the wanted products. $225 \mathrm{Ra}$ normally is not dissolved and, depending on the acid and acid concentration used, at least $90 \%$ of it remains with the waste products. When it is with waste products, it can be removed frow the soluble waste, as it can be removed from water, by treatnent with slaked line. 20 Lime neutralization is about $90 \%$ effective with heavily contaminated waste products or with relatively pure drinking water. Its chief advantage is low cost. Slaked-lime treatment is used in comunity drinking systems as well, and thereby can be used both as a process of treating waste effluents before they reach the aquatic environment and as a method to reduce the amount of ${ }^{226} \mathrm{Ra}$ in drinking water. Other chemicals used in acidic removal of radioactivity from waste products are: ammonia, sodiun hydroxide, and barium chloride.

The cost of treatment of phosphate and uranium waste products can be partially offset by increasing the recovery rate of wanted products such as uranium. High prices for uranium increase the incentive to improve removal of radionuclides. More expensive treatment includes ion-exchange technology, which has been successfully employed to increase uraniun recovery in uranium production and more recently on a pilot basis as a by-product in phosphate production. $20-22$ Removal rates are in excess of $96 \%$.

In those areas where phosphate and uranium:are mined, removal of ${ }^{226} \mathrm{Ra}$ from mining wastes may be a cost-effective approach to nondegradation of water quality. The incremental cost to the companies involved may be minimal in new operations, owing to the increasing opportunity to amortize the cost by improved uranium recovery. Water-quality benefits may be derived, but they will be realized only where mining takes place.

However, for the Great Lakes the only direct application would involve uranium-mining activity in the Elliot lake area, effluents from which may impact lake Huron: "Canada's major uranium mining operation is situated north of Lake Huron in the Elliot Lake area which drains to the North Channel from Serpent River. This river system is contaminated with 226 Ra from tailings pond seepage."23 The other examples where adsorption in ion-exchange technoiogy may be cost-effective are in the continual management of the closed nuclear-fuel-reprocessing plant in West Valley, New York, and the uranium-refining and $\mathrm{UF}_{6}$-production plant near Port Hope, Ontario. 23 In both 
cases further study of cleanup technology may be fruitful, but neither case involves a health consequence of the magnitude to affect a Great Lakes radioactivity objective for the whole basin.

The cleanup of effluents from the man-made sources discussed above does not appear to be an effective scheme to reduce the concentration of radionuclides in the Great Lakes. This conclusion is based primarily on the relatively insignificant contribution by fertilizer to existing naturally occurring levels of ${ }^{226} \mathrm{Ra}$. Specific cases, e.g. Lake Elliot, of effluent-discharge treatment may indeed develop as cost-effective cleanup strategies.

\subsection{REMOVAL OF ${ }^{226}$ RADIUM FROM DRINRING WATER}

Although the general objective of this study is the examination of the effects of ingestion of "raw" lake water (as a basis for establishing a nondegradation objective), it is also possible to consider the proposed onemillirem objective from the standpoint of treating existing lake-pollutant levels so as to achieve health objectives commensurate with the one-millirem objective. From the viewpoint of cost-effectiveness, the best case for water treatment in terms of health can be made with respect to treating drinking water. Under the assumption that between $90 \%$ and $99.9 \%$ of all ${ }^{226} \mathrm{Ra}$ can be removed from drinking water, the benefits and costs of such treatment are examined. Removal rates depend on the technology examined; the benefits and costs depend on removal rates and technology costs. The nost total benefits are realized by ${ }^{226} \mathrm{Ra}$ removal because the isotope is a major dose contributor to man from ingestion of raw water.

Because ${ }^{90} \mathrm{Sr}$ and ${ }^{226} \mathrm{Ra}$ are chemically similar, ${ }^{90} \mathrm{Sr}$ may be removed along with ${ }^{226} \mathrm{Ra}$, but it is not clear how much $90 \mathrm{Sr}$ wi11 be removed. The removal of ${ }^{226} \mathrm{Ra}$ appears to be the most effective and least costly way to reduce the dose commitment to man, based on its significance as a dose contributor and on known removal processes.

To the extent that the one-millirem objective makes sense on cost-benefit criteria, it will succeed or fail on the $226_{\mathrm{Ra}-r e m o v a l}$ example. ${ }^{226} \mathrm{Ra}$ removal from Great Lakes drinking water represents the limiting case for a total Great Lakes radioactivity objective for two reasons. The cost of treating water is proportional to the volume of watex treated; and by limiting the case to public water systems, the ${ }^{226} \mathrm{Ra}$ reduction is proportional to the reduction in radiation received by man.

\subsection{RADIUM REMOVAL - 1970 AND 2030}

For the purpose of this assessment, it is assuned that slaked-1ime or Ion-exchange-resin treatment are not now part of any significant portion of community water systems using lakes waters. Such treatment is usually considered a tertiary water-treatment strategy. These two generic treatment strategies are evaluated in terms of two levels of efficiency: $907{ }^{226} \mathrm{Ra}$ removal for slaked lime and 99.97 removal for lon-exchange processes. For illustrative purposes, all the benefits from the one-niliirem objective are assumed to derive from ion-exchange drinking-water treatwent. The calculated TED $_{50}$ received by all people drinking comunity water each year for 50 years 
would range from 0.2 mrem to 445 mrem, depending on treatment efficiency and source of water. This range reflects the best and worst situations that existing evidence may indicate, as well as the uncertainties that are associated with extrapolation from few data.

It may be argued that further treatment of drinking water results in a benefit far in excess of benefits realized by ${ }^{226} \mathrm{Ra}$ removal alone. For the purpose of setting a Great Lakes radioactivity objective, this argument is not addressed. This assessment addresses only the costs and berefits of water treatment for reduction of radioactivity levels. Treatment of water with salt to remove hardness is not considered. The controversial link between softened water and cardiovascular disease is presumed to be real enough as to preclude this option. 24 The benefits derived from further treatment are considered only in terms of ${ }^{226} \mathrm{Ra}$ renoval rather than reduced hardness in water or the removal of other trace elements.

The view is taken that the benefits of cleanup would increase in the future owing to an increasing population served by the Great Lakes for drinking water. It is assumed that 25 million people are now being served by the Great Lakes for municipal and rural water consumption. This figure would increase to 82 million people by the year 2000 when $90 \%$ of the people of the Great Lakes Basin will consume Great Lakes water. 25,26

\subsection{THE COSTS OF DRINKING-WATER TREATMENT}

In examining the incremental cost of ${ }^{226} \mathrm{Ra}$ removal to meet the radioactivity-level standard for drinking water of $5 \mathrm{pCi} / 1$, EPA estimated the annual cost per person. 27 The presumed technology was zeolite ion exchange and the assumed efficiency was $97 \%$. To decrease the initial concentration in water from $1 \mathrm{pCi} / 1$ to about $0.1 \mathrm{pCI} / 1$, EPA reported the annual cost per person to be $\$ 5.48$ in 1975 . EPA's primary interest was the cost to small communitywater systems, and the economies of scale of construction were not considered in its estimate. Nevertheless, comparison with similar treatment estimates indicate that capital costs are less than $20 \%$ of the annual operation cost of ion-exchange processes. 28,29 A more serious problem is the assumption that only part of the raw water passing through the system had to be treated: "Usually only a fraction of the supply water need be treated since the mixing of treated and untreated water is acceptable abatement procedure." 30 Using the EPA formula for estimating how much water must be treated to reduce the level from $1 \mathrm{pCi} / 1$ to $0.001 \mathrm{pCi} / 1$, it can be shown that all the municipal water from the Great Lakes must be treated.

Several studies on ion exchange indicate the cost of treatment. Based on studies of several ion-exchange-process alternatives for 12 communities, a range of costs of 29 cents to $\$ 1.25$ per thousand gallons of water treated was reported. 28 All of the communities examined had extremely poor, brackish, municipal-water supplies. The primary purpose was to remove the hardness and sodium from the water. A slightly lower capital cost was estimated for iorexchange equipment for removal of ${ }^{226} \mathrm{Ra}$ for plants with a capacity of five to ten million gallons per day. ${ }^{31}$ The annual cost estimated by Bresler and Miller ranges from 30 to 40 cents per year per 1000 gallons treated at a $90 \%$ on-stream rate. 32 
At 30 cents per 1000 gallons for a treatment of three million gallons per day, the cost to a small comunity would be about $\$ 330,000$ per year. If such a community consumed 100 gallons per person per day then treatnent would cost no less than $\$ 11.00$ per person per year. The less expensive approach using IIne-soda ash would indicate the lower bound on treatment cost. The city of 0sosso, Michigan, spent about $\$ 76,000$ in 1976 on lime for its 2.63-milliongallon-per-day plant. ${ }^{33}$ At a consumption of 100 gallons per day, lime costs were about $\$ 3.00$ per perso excluding associated labor costs and depreciation.

The total costs of treatment are estimated using a variety of assumptions as given In Table 13.

Total annual costs range from $\$ 160$ million per year to over $\$ 2.19$ billion per year depending on assumptions. Obviously, a large proportion of the treated water sould never actually be Ingested.

Another approach to water treatment is to have all households invest in home water conditfoners. This would cost in the range of $\$ 1.4$ billion dollars per year at current water-softener prices.

Total cost to remove $90 \%$ of the ${ }^{226} \mathrm{Ra}$ prior to ingestion would be expected to be no less than about $\$ 160$ million each year. However, this cost could be about \$2.2 billion per year to demonstrate progress toward the one-millirem objective for water that would actually, or potentially, be consused on a dafly basis by resfdents of the Great Lakes basin.

Table 13. Total Treatment Costs per Year for the Great Lakes (millions of do1lars)

\begin{tabular}{|c|c|c|c|c|c|}
\hline & & & & & \\
\hline & & $\underline{L i}$ & Ash & Ion & 200 \\
\hline & $\begin{array}{c}\text { Water } \\
\text { Treatment }\end{array}$ & $\begin{array}{l}\text { At } 10 \text { per } \\
1000 \text { gallons }\end{array}$ & $\begin{array}{l}\text { At } 20 \mathrm{f} \text { per } \\
1000 \text { gallons }\end{array}$ & $\begin{array}{l}\text { At } 30<\text { per } \\
1000 \text { gollons }\end{array}$ & $\begin{array}{l}\text { At } 605 \text { per } \\
\text { 1000 gallon: }\end{array}$ \\
\hline 2 & $\begin{array}{l}\text { Treatment of all } \\
\text { U.S. micipal water } \\
\text { supplifed at current } \\
\text { capacity of } 7409 \mathrm{Mgd}\end{array}$ & 270.4 & 540.8 & 811.2 & 1622.4 \\
\hline 2 & $\begin{array}{l}\text { Treatment of all } \\
\text { U.S. minicipal } \\
\text { consumption (1970) } \\
\text { of } 4356 \mathrm{Hgd}\end{array}$ & 159.0 & 318.0 & 477.0 & 954.0 \\
\hline 3 & $\begin{array}{l}\text { Treatsent of al1 } \\
\text { Canadian mmicipal } \\
\text { and rural water uar } \\
\text { (1965) of } 887 \mathrm{Hgd}\end{array}$ & 32.3 & 64.6 & 96.9 & 193.8 \\
\hline 4 & $\begin{array}{l}\text { Treatment of all } \\
\text { Canndian municipal } \\
\text { and rural water use } \\
(2030) \text { of } 2592 \text { Hgd }\end{array}$ & 94.6 & 189.2 & 282.8 & 567.6 \\
\hline 5 & $\begin{array}{l}\text { Total In the year } \\
2030 \text { (1ines } 1 \text { plus 4) }\end{array}$ & 365.0 & 730.0 & 1095.0 & 2190.0 \\
\hline
\end{tabular}


The cost of treatment depends on the efficiency of the treatment processes, which are assumed to range from $90 \%$ to $99.9 \%$. At this time, the staff could not determine the precise efficiency of any given ion-exchange technology. Consequently, it must be assumed, at this time, that it way cost $\$ 2.2$ billion per year to achieve $90 \%$ efficiency. This is a wost conservative assumption, given that the scale of operation has no precedent and would require indirect costs of large magnitude. Also, efficiency would be difficult to maintain over hundreds of individual operations.

The ${ }^{90} \mathrm{Sr}$ concentration appears similar in a11 the Great Lakes and ranges from 0.6 to $1.0 \mathrm{pCi} / 1$. This concentration produces a $\mathrm{TED}_{50}$ for whole body of 0.7 to 1.2 mrem, and the corresponding dose to bone is 7-12 mrem. Thus, even if ${ }^{226} \mathrm{Ra}$ were removed completely, further reduction of $90 \mathrm{sr}$ would be required to achieve a one-millirem objective for whole body or a six-millirem objective for bone. The only feasible way to achieve a one-millirem objective is by an ion-exchange process, which could rewove up to $90 \%$ of both ${ }^{226} \mathrm{Ra}$ and ${ }^{90} \mathrm{Sr}$.

Estimates of the value and cost of rewoving ${ }^{90} \mathrm{Sr}$ from drinking water such as those reported above for ${ }^{226} \mathrm{Ra}$, should be performed. It is assumed that the value of ${ }^{90} \mathrm{Sr}$ removal will be of the same order of magnitude as that of ${ }^{226} \mathrm{Ra}$ removal:

$$
\frac{\$ 2.18 \text { to } 4.62 / \mathrm{yr}}{\mathrm{pCi} / 1}
$$

The staff believes that the relatively inexpensive (slaked-1ime) ${ }^{226} \mathrm{Ra}$-removal process will remove sowe of the ${ }^{90} \mathrm{Sr}$ and that the relatively expensive (ion-exchange) ${ }^{226} \mathrm{Ra}-\mathrm{removal}$ process may remove as much as $99 \%$ of the ${ }^{90} \mathrm{Sr}$. If removal of both ${ }^{226} \mathrm{Ra}$ and ${ }^{90} \mathrm{Sr}$ by the slaked-lime process achieves a high degree of efficiency , $3 \%$ or more), then there may be some value to examining thoroughly the costs and benefits of treating drinking water. Further consideration would include a closer examination of all the elements of health risk, technological efficiency, and possible side effects associated with treatment processes.

\section{COST-BENEFIT SIMMARY}

This section summarizes the considerations in Sections 6 and 7 . The most cost-effective method of reducing che dose resulting from ingestion of drinking water dram from the Great Lakes is to reduce the concentration of radionuclides in the water after it is withdrats and before Ingestion. The most important sources of harm appear to be ${ }^{226} \mathrm{Ra}$ and ${ }^{90} \mathrm{Sr}$. A rough estimate of the cost and efficiency of removing ${ }^{226} 6_{\mathrm{Ra}}$ has been made. The degree to which the processes of $226 \mathrm{Ra}$ removal will also remove ${ }^{90} \mathrm{Sr}$ has not been estimated. A rough estimate of the annual amount of money Americans might be willing to spend to reduce the concentration of ${ }^{226} \mathrm{Ra}$ in their drinking water in order to reduce the projected somatic harm to thenselves and their children has been made also.

The result of these estimates is that a $90 \%$ reduction in the concentration of $226 \mathrm{Ra}$ could be achieved for $\$ 160 \times 10^{6} / \mathrm{yr}$ to $\$ 2200 \times 10^{6} / \mathrm{yr}$ and that this range is not very dependent on the population $\left(25 \times 10^{6}\right.$ in 1970 or 
$80 \times 10^{6}$ in 2030) to be served. It also appears possible to reduce the concentration of ${ }^{226} \mathrm{Ra}$ by $99.9 \%$, but this cost may be at the high end of the range because of the vast scale of operations that would be necessary relative to existing experience. Assuming that two-thirds of the population are adults, this implies an annual range of costs per adult between $\$ 9.60$ and $\$ 132.00$ for a $90 \%$ reduction in ${ }^{226} \mathrm{Ra}$ for the 1970 population of $25 \times 10^{6}$ persons and an annual range per adult of $\$ 3.00$ to $\$ 41.25$ for a population of $80 \times 10^{6}$ persons. This $90 \%$ reduction in ${ }^{226} \mathrm{Ra}$ concentration would result in a change of $0,018 \mathrm{pC} / 1$ in drinking water drawn from Lake Michigan and changes of 0.9 to $2.7 \mathrm{pCi} / 1$, 0.9 to $4.95 \mathrm{pCi} / 1$, and $0.027 \mathrm{pCI} / 1$ in drinking vater drawn from Lakes Furon, Ontario, and Erie, respectively. The reader should bear in mind that the staff does not know the concentration of ${ }^{226} \mathrm{Ra}$ in Lake Superior. Because the range of $\$ 1.69$ to $\$ 4.00 / y$ per $p C 1 / 1$ was designated as a rough estinate of what the persons affected would spend to reduce the concentration of ${ }^{226} \mathrm{Ra}$ in their drinking water, one could infer that a $226_{\text {Ra-reduction goal for Lake }}$ Michigan would not win widespread appreciation. However, such a program for removal is not ruled out on cost-benefit grounds for Lakes Huron and Ontario. It is emphasized that the staff"s considerations are only approximate in nature, should be further refined, and have been restricted to the three sets of issues described in Section 6.1.1. Consideration should also be given to the issues not covered by this report, which were also cited in Section 6.1.1, before draving conclusions based on cost-benefit considerations. Also, the reader should bear the following questions in aind: "What are the concentrations of radionuclides in Lake Superior?" "What is the likelihood that the Great Lakes will be used to supply untreated drinking water?" "How does the radiation that would be received from this water compare to other natural and man-made sources?"

To place these questions in context for further consideration, Table 14 summarizes average radiation dose to man from a variety of sources. Additional radiation received from ingestion of 2.2 1iters of raw water would add $2-4 \mathrm{mrem} / \mathrm{yr}$ from ${ }^{226} \mathrm{Ra}$ and $1.2 \mathrm{mrem} / \mathrm{yr}$ from ${ }^{90} \mathrm{Sr}$. This additional $226_{\mathrm{Ra}} \pm 6$ based on the assumption of an average concentration in lakes waters of 1 pCi/1.

Further considerations are the standards that already exist specifically for ${ }^{226} \mathrm{Ra}$. These standards are expressed in activity levels (pCi/1) rather than dose effects. Standards are shown in Table 15, and these can be compared with the "in-lake" levels given in Table 4.

It appears that acceptance of the one-milliren objective inplies a need for actions to reduce current levels of ${ }^{226}$ Ra activity in the lakes. Before such actions are wndertaken, the foregoing fundanental questions should be examined. A better baseline radioactivity condition must be defined. A better view is required of natural vs. man-made source contributions to the lakes.

\section{RECOMMEMATIONS FOR FURIHER ASSESSNENTS BY THE DIVISION OF TECHNLOGY OVERVIEN (DTO)}

The DTO request for a short completion time placed clear 1inits on the completeness with which aspects of the study could be treated. Horeover, as the study progressed, we Identified questions and problew areas beyond the original scope of the study. This section deals briefly with these matters. 
Table 14. Sources of Whole-Body Doses

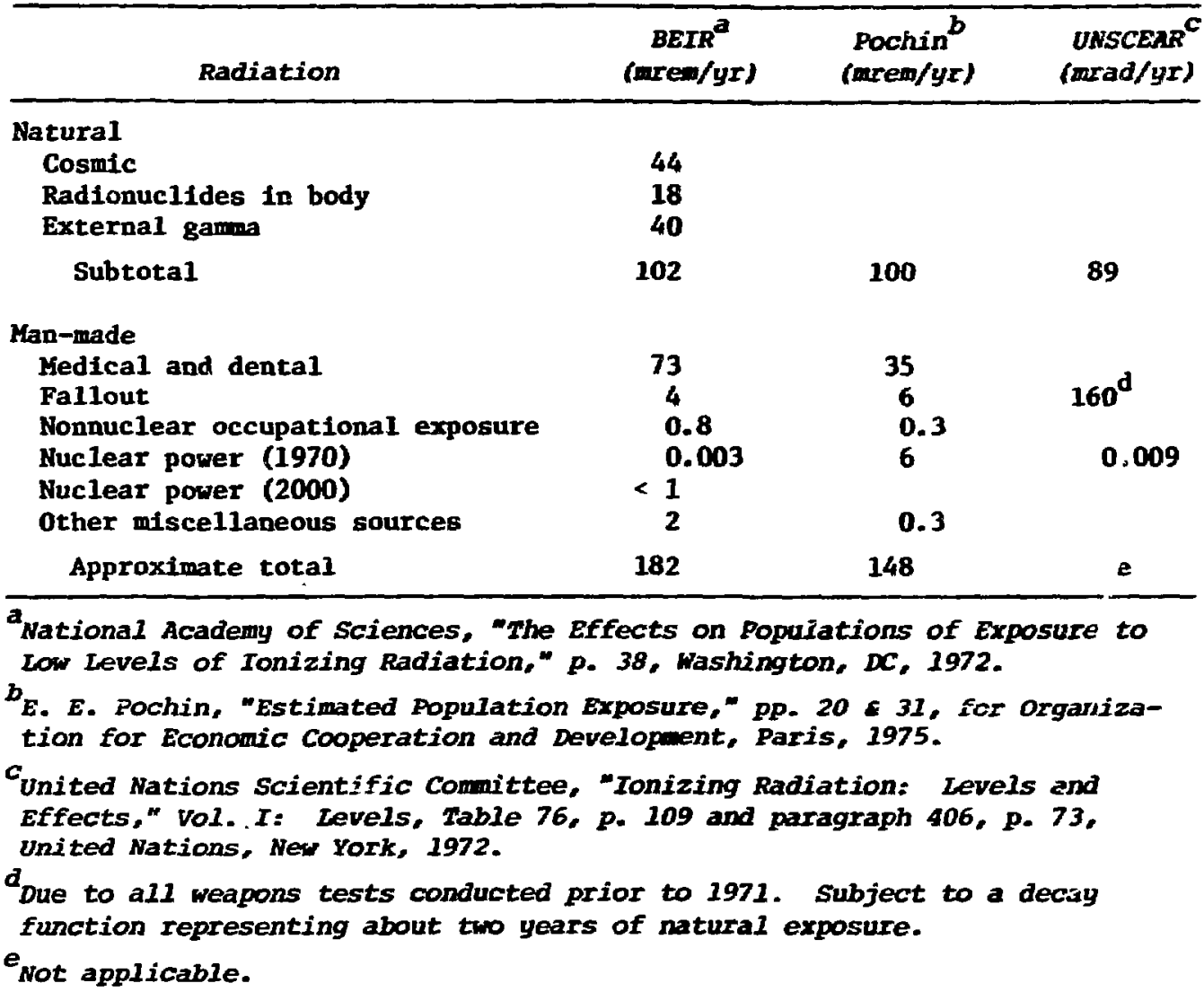

Topics not specifically considered were:

(1) detailed demography and computation of population-dose comitments (man-ren) for persons drinking water from each lake,

(2) quantitative identification of specific source terms (i.e. Input sources of radioactivity),

(3) the acceptance of existing levels of radioactivity as a reasonable new base for nondegradation, and

(4) costs for mitoring prograws in support of a onemillirem objective. 
Table 15. ${ }^{226}$ Badium Activity Levels (pci/1)

\begin{tabular}{|c|c|c|}
\hline Water Systems and Lakes & Level & Source \\
\hline $\begin{array}{l}\text { Range of "alues in public supply } \\
\text { systems }\end{array}$ & $0.1-60$ & $\begin{array}{l}\text { EPA, } 40 \text { FR } 34325,14 \text { August } \\
1975\end{array}$ \\
\hline $\begin{array}{l}\text { Recommended standard for drink- } \\
\text { ing water by interstate carriers }\end{array}$ & 3.0 & $\begin{array}{l}\text { U.S. Public Health Service, } \\
\text { "Drinking Water Standards," } \\
\text { Pub1. 956, } 1962\end{array}$ \\
\hline $\begin{array}{l}\text { Maximum contaminant levels in } \\
\text { colmunity water systens }\end{array}$ & 5.0 & $\begin{array}{l}\text { EPA, } 41 \text { FR 28404, } 9 \text { July } \\
1976\end{array}$ \\
\hline $\begin{array}{l}\text { NPDES-permit limication for sol- } \\
\text { uble disposal by release into } \\
\text { sanitary sewage systems }\end{array}$ & 30.0 & $\begin{array}{l}10 \text { CFR 20, Appendix B, } \\
\text { Table II }\end{array}$ \\
\hline Lake Mfchigan & 0.02 & Table 2 \\
\hline Lake Ontario & $<1.0-5.5$ & Table 4 \\
\hline Lake Erie & 0.03 & Table 4 \\
\hline Lake Huron & $0.1-3.0$ & Table 4 \\
\hline
\end{tabular}

Further consideration should be given to:

(1) development of specific protocols for isotope-monitoring programs,

(2) deterwination of the accuracy of the reported isotope concentrations in Great Lakes waters,

(3) prediction of the impact of reducing input from controllable sources to radioactivity concentrations in Great Lakes waters,

(4) more detailed cost-benefit analysis concerning costs of ${ }^{226} \mathrm{Ra}$ and ${ }^{90} \mathrm{Sr}$ removal, and

(5) epideniological studies of populations that are known to ingest levels of ${ }^{226} \mathrm{Ba}$ in excess of those reported for the Great Lakes.

\section{FUTURE RESEARCH NEEES}

It is clear fron the data presented in this report that we know far more regarding the behavior of the fission products and transuranic elements in the Great Lakes than we do about the radionuclides in the natural uranium and thorium series. It is imperative that a major effort be made to describe the sources, transport, and fate of ${ }^{226} \mathrm{Ra}$ in the Great Lakes. Considering that reported values for ${ }^{226} \mathrm{Ra}$ in lake waters vary between 0.02 and $5 \mathrm{pCi} / 1$, and 
that even at the lowest concentration the TED $_{50}$ will be within a factor of two of the proposed standard of one millirem, top priority should be alaced on experiments to determine the concentration of ${ }^{22} \epsilon_{R a}$ in lake waters and to assess the temporal and spatial variations.

Although it is well known that $210_{\mathrm{Pb}}$ (another daughter in the ${ }^{238} \mathrm{U}$ decay series) is concentrated in surficial sediments, due to natural fallout following decay of ${ }^{222} \mathrm{Ra}$ in the atmosphere, few observations have been made of the distribution of ${ }^{226} \mathrm{Ra}$ in the sediments. It is wel1 know that ${ }^{226} \mathrm{Ra}$ can enter the lakes as a result of mining and milling operations, runoff from agricultural fields after the application of phosphate fertilizers, and wet and dry deposition of airborne particulates released in the burning of coal. Because little is know. regarding the biogeochemistry of ${ }^{22} \sigma_{\mathrm{Ra}}$, studies should be initiated to determine its pathways in the aquatic environment and its availability to organisms through the water itself and the food chain. Such studies should include the determination of the chemical form of ${ }^{226} \mathrm{Ra}$ and other natural radionuclides and the relative importance of biotic and abiotic processes, such as uptake by phytoplankton and inorganic particulate matter in the water column, in their transport and fate within the system. A full knowledge of such processes is essential if we are to be able to predict the resulting concentrations of these radionuclides in drinking waters.

\section{SIMMARY}

Current measurements indicate that naturally occurring ${ }^{226} \mathrm{Ra}$ and ${ }^{90} \mathrm{Sr}$ from fallout are the greatest contributors to radiation dose for percons drinking water from the Great Lakes. Levels of radioactivity in Great Lakes waters are neither well documented nor known accurately. Therefore, a large margin of uncertainty must also be attached to the total equivalent dose-50 years $\left(\mathrm{TED}_{50}\right)$ estimates provided. The radioisotope data for lake superior were insufficient for meaningful $T E D_{50}$ calculations. TED 50 estimates for water from the other lakes are in excess of the one-millirem objective for whole body or other critical organs. TED 50 estimates for gonads also exceed 1 mrem for Lakes Huron, Ontario, and Erie if the upper range of reported isotope concentrations is used for dose calculations. Doses to man that result from ingestion of water from the Great Lakes are not expected to decline by 2050 . Because consumption for only one year is considered, the $\mathrm{TED}_{50}$ criterion underestimates the potential health effects that may result from ingestion of lake water. Reduction of controllable isotope releases from the sources would not be expected to reduce $T_{50}$ appreciably. TED 50 could be influenced by treating water after its removal from the lakes. Cost-benefit considerations support the policy of ${ }^{226} \mathrm{Ra}$ and ${ }^{90} \mathrm{Sr}$ removal, and the concomitant reduction of dose to man, through treatment of water before ingestion. Although this procedure is considered cost-effective in an overall sense, large expenditures would be necessary to achieve the ons-millirem objective after ingestion of waters from Lakes Huron, Ontario, and Erie. Such treatment of water from Lake Michigan could reduce $\mathrm{TED}_{50}$ to less than 1 mrem for whole body and gonads and to less than 6 mrem for bone. Adoption of the revised water-quality objective of one millirem for Great Lakes water is prenature and should be delayed until the levels of radioactivity in Great Lakes waters are established more accurately. Further assessuent of the efficiency of ${ }^{226} \mathrm{Ra}$ and ${ }^{90} \mathrm{Sr}$ removal and a more comprehensive cost-benefit analysis are necessary. 


\section{REFERENCES}

1. F. W. Spiers. "Radioisotopes in the Buman Body." Acadenic Press, New York, p. 286, 1968.

2. P. J. Barry. "Estinated Dose Cowaitwent to Populations from Radioactive Waste Disposals into large lakes." Paper Mo. SH-172-43, IAEA Symp. on Environ. Behavior of Radionuclides Released in the Muclear Industry, Vienna, pp. 499-506, 1973.

3. D. N. Edgington and E. Callender. "Hinor Element Geochemistry of Lake Michigan Ferromanganese Nodules." Earth and Planetary Science Letters 8:97-100, 1970.

4. A. Lerman. "Strontium 90 in the Great Lakes: Concentration-Time Hodel." J. Geophys. Res. 77:3256-3264, 1972 .

5. W. P. Norris, S. A. Tyler, and A. H. Brues. "Retention of Radioactive Bone-Seekers." Science 128:456-462, 1958.

6. P. F. Gustafson. "Future Levels of Tritium in the Great Lakes from Nuclear Power Production." Proc. 13th Conf. Great Lakes Res., Int. Assoc. Great lakes Res., pp. 839-843, 1970.

7. R. Thaler and S. Rosen. "The Value of Saving a Life: Evidence from the Labor Market." Paper presented at the NBER Conference on Income and Wealth, Household Production and Consunption, Washington, DC, 30 Noverber 1973.

8. R. S. Smith. "The Feasibility of an Injury Tax Approach to Occupational Safety." Lav and Contemporary Problens, Sumer-Autumn, 1974.

9. R. S. Smith. "The Occupational Safety and Health Act." American Enterprise Institute for Public Policy Research, Washington, DC, 1976.

10. พ. K. Viscuzzi. "Ioplicit Market Valuaticn of Life and Limb: New Evidence from the Labor Karket." Report prepared for Argonne National Laboratory, May 1977.

11. J. Facer, Jr. "Production Statistics." USERDA, Supply Analysis Division, p. 10, October 1976.

12. "Great Lakes Basin Framework Study: Land Use and Kanagenent." Great Lakes Basin Comilssion, Appendix 12, Table 13-39, p. 45, 1975.

13. "Statistical Abstract of the U.S." U.S. Dept. of Comerce, P. 636, 1975.

14. พ. F. Holland et al. "Enviromental Effects of Trace Elements from Ponded Ash and Scrubber Sludge." Report 202, Electric Power Research Institute, Palo Alto, CA, 1975.

15. "Environmental Phosphorus Handbook." Griffith, Beeton, Spencer, and Mitchell, eds., pp. 689-690, John wiley, New York, 1973. 
16. J. Lunin, "Advances in Environmental Science and Technology." J. N. Pitts and R. L. Metcalf, eds., Interscience, New York, 1971.

17. V. Sanche111. "Phosphorus in Agriculture." The Davidson Chentcal Corp." Baltimore, MD, 1951.

18. "Radioactivity Distribution In Phosphate Products, By-Products, Effluents, and Hastes." USEPA, Office of Radiation Prograns, CRP/CSD-75-3, August 1975.

19. T. J. Murphy. "Concentrations of Phosphorus in Precipitation in the Lake Michigan Basin." Journal of Great Lakes Research, Vol. I, Supp. 1, pp. 127-131, Ann Arbor, MI, 1976.

20. "Uranium Miling Operations - Generic Environmental Statement." USKRC, in preparation.

21. R. C. Ross. "Uranim Recovery fron Phosphoric Acid Nears Reality as a Commercial Uranfum Source." Engineering and Mining Journal 176(12):80-85, December 1975.

22. Letter to T. L. Winters, ANL, from Irwin Higgins, Chenical-Separations Corp., Oak Ridge, TX, 1 June 1977.

23. "Great Lakes Water Quality." Appendix D, Radioactivity Subcomittee Report, International Joint Corerission, Great Lakes Water Quality Board, p. 7, 1975 .

24. H. E. Hudson and F. W. Gilcreas. "Health and Econonic Aspects of Water Hardness and Corrosiveness." J. Am. Water Works Assoc., Pp. 201-204, April 1976.

25. Op. cit., Reference 12, Appendix 6, p. 29.

26. "A Survey of Consumptive Use of Water in the Great Lakes Basin." International Great Lakes Levels Board, pp. 14-16, September 1969.

27. "Statement of Basis and Purpose for the National Interim Primary Drinking Water Regulations: Radionuclides." USEPA, Office of Radiation Programs, Criteria and Standards Division, pp. 66-71, 9 July 1976.

28. S. A. Bresler and F. F. Miller. "Econonics of Ion Exchange Techniques for Hunicipal Water Quality Improvement." J. Am. Water Works Assoc., pp. 764-772, November 1972.

29. I. R. Higgins. "Ion Exchange: Its Future and Present Use." Environ. Sci. Technol. $7(8)=1110-1114,13$ December 1973.

30. Op. c1t., Reference 27, p. 67.

31. Persona1 communication with Rent McGrew, Chemica1-Separations Corp., Oak Ridge, TN, Hay 1977. 
32. Op. c1t., Reference 28, Table 9, p. 771.

33. A. R. Singhal. "Conventional Lime Soda Ash Softening vs. Split Treatment of the Owosso, Michigan, Water Treatment Plant." J. Am. Water Works Assoc., Pp. 158-161, Harch 1977. 


\section{APPENDIX A}

The generalized equation that determines the activity of a radioisotope in an organ of reference after ingestion is:

$$
q(t)=\operatorname{pCfH}(t)
$$

where:

$$
\begin{aligned}
& t=\text { time after ingestion, } \\
& p=\text { amount of food or Ifquid consumed per day, } \\
& C=\text { concentration of radioisotopes in substance } \\
& \text { consumed, } \\
& \mathbf{f}=\mathrm{f}_{1} \mathrm{f}_{2} \text {, } \\
& f_{1}=\text { fraction of isotope that enters bloodstream from } \\
& \text { the intestinal system, } \\
& f_{2}=\text { fraction of isotope that passes from blood to organ } \\
& \text { of interest (this constant depends on the retention } \\
& \text { function used), and } \\
& H(t)=\text { fraction of 1sotope remaining in organ of interest } \\
& \text { (this includes both the blological retention function } \\
& \text { and physical-decay properties). }
\end{aligned}
$$

EXPONENTIAL RETENTION FUNCTION

During an interval of continuous ingestion, the activity present in the organ of interest is determined by:

$$
\frac{d q}{d t}=p C f_{w}-\lambda q
$$

where:

$$
\begin{aligned}
f_{w}= & f_{1} f_{2}^{\prime}, \\
f_{1}= & \begin{array}{l}
\text { fraction of radioactivity that reaches the } \\
\text { bloodstream from the intestinal tract, }
\end{array} \\
f_{2}^{\prime}= & \begin{array}{l}
\text { fraction of } f_{1} \text { activity that reaches the organ of } \\
\text { interest, and }
\end{array}
\end{aligned}
$$




\section{$\lambda=$ effective decay constant that deternines residency time in organ of interest;}

and:

$$
\lambda=0.693\left[\frac{T_{b}+T_{p}}{T_{b} T_{p}}\right]
$$

where:

$$
\begin{aligned}
& T_{b}=\text { blological half-life for specific organ, and } \\
& T_{p}=\text { physical half-life. }
\end{aligned}
$$

Thus the activity in the organ after time $t$ is:

$$
q(t)=\frac{\text { PCf }_{w}}{\lambda}\left[1-e^{-\lambda t}\right]
$$

The integrated organ burden (activity $\times$ time) over the interval of consumption is:

$$
Q(t)=\frac{P C F_{w}}{\lambda}\left[t+\frac{1}{\lambda}\left(e^{-\lambda t}-1\right)\right]
$$

For the time interval following termination of injection the activity in the organ of interest is:

$$
q(t)=q\left(t_{0}\right) e^{-\lambda t}
$$

where:

$$
q\left(t_{0}\right)=\text { activity at the time injection terminates. }
$$

The integrated organ burden in activity-days is:

$$
Q\left(t-t_{0}\right)=\frac{q\left(t_{0}\right)}{\lambda}\left[1-e^{-\lambda\left(t-t_{0}\right)}\right]
$$

POWER RETENTION FUNCTION

Frequently, the complicated metabolic pathways yield retention characteristics that are best described by several independent first-order exponential terms. It has been demonstrated by Norris et al.* that such a sum of exponentials can be represented over a large interval by a single power function. This function has the form:

$$
R(t)=A t^{-n}
$$

\footnotetext{
${ }^{*}$ Reference 5 of the main text.
} 
where:

$$
\begin{aligned}
R(t)= & \text { fraction of activity remaining after time } t \text {, and } \\
A= & \text { fraction of isotope remaining after the first day } \\
& \text { following injection. }
\end{aligned}
$$

The instantaneous rate of excretion is then:

$$
\frac{d R}{d t}=-\frac{n}{t} R \quad \text { for: } t \geqq 1
$$

Including the physical-decay process, the activity following a single injection is:

$$
\begin{aligned}
\frac{d q}{d t} & =-\frac{n}{t} q-\lambda_{p} q & \left(\lambda_{p}=\frac{0.693}{T_{p}}\right) \\
q(t) & =q_{0} t^{-n_{e} \lambda(1-t)} & \text { for: } t \geqq 1 \\
q_{0} & =p \operatorname{cfA} &
\end{aligned}
$$

where:

$$
\begin{aligned}
f= & f_{1} f_{2}, \\
f_{1}= & \text { fraction of injected isotope that transfers from intes- } \\
& \text { tinal tract into bloodstream and is eventually excreted } \\
& \text { according to } R(t), \text { and } \\
f_{2}= & \text { fraction of isotope retained according to } R(t) \text { that is } \\
& \text { associated with the organ of interest. }
\end{aligned}
$$

The body burden resulting from daily ingestion over a days and integrated over a total interval of $M$ days is:

$$
Q(t)=(M-m) \sum_{t=1}^{M-m} q(t)+\sum_{t=1}^{m}(m+1-t) q(M-n+t)
$$

When the physical half-1ife is much greater than the biological retention time, the integrated burden for instantaneous uptake can be solved directly:

$$
Q(t)=q_{0} \frac{t^{I-n}}{1-n}
$$

It should be emphasized that the exponential retention function contains an effective decay constant associated only with a specific organ. Thus, $f$ refers to the fraction transferred directly to that organ. The power function refers to the retention in the whole body. The fraction $f$ refers only to that remaining whole-body portion located at or assoclated with the organ of interest. For example, $30 \%$ of the ingested ${ }^{226} \mathrm{Ra}$ is transferred from the GI 
tract to blood and subsequently excreted according to a power function. Almost all of the retained ${ }^{226} \mathrm{Ra}$ (99\%) is associated with exchange processes in the bone.

A more detailed retention function for allaline-earth elements has been proposed in ICRP-20. We have compared the bone-dose comnitment as computed from this model for ${ }^{226} \mathrm{Ra}$ with the simple power function and obtained results that compare within $15 \%$.

DOSE CALCULATION

The following i atationship is used to convert the time-integrated burden $Q(t)$ to dose (from I(RP-II):

$$
\text { Dose }(\text { mrem })=\frac{\text { EFRBE } \times 51.2}{g} Q
$$

where:

$$
\begin{aligned}
\text { EFRBE }= & \text { Effective energy (MeV) of all the decay products } \\
& \text { adjusted according to appropriate quality factors, } \\
Q= & \text { organ burden in } \mu \text { Ci-days, and } \\
g= & \text { mass of organ in grams. }
\end{aligned}
$$

\begin{tabular}{|c|c|c|c|c|c|c|c|c|c|}
\hline Nuclide & sigan & $f_{1}$ & $f_{2}$ & $E_{2}$ & $f$ & $x_{b}$ (anys) & $T_{p}$ (days) & EFREE & Mess (g) \\
\hline${ }^{3} \mathbf{m}$ & $\mathrm{HB}^{\mathrm{a}}$ & 1.0 & 1.0 & & 1.0 & 12 & 4,500 & 0.01 & 70 \\
\hline${ }^{137} \mathrm{Cs}$ & WB & 1.0 & 1.0 & & 1.0 & 70 & 11,000 & 0.59 & 70 \\
\hline${ }^{90} \mathrm{Sr}$ & $\mathbf{H B}$ & 0.3 & 1.0 & & 0.3 & 13,000 & 10.000 & 1.1 & 70 \\
\hline${ }^{90} \mathbf{S r}$ & Bone & 0.3 & 0.3 & & 0.09 & 18,000 & 10,000 & 5.5 & 7 \\
\hline${ }^{90} \mathrm{Sr}$ & Bone & 0.3 & & 0.99 & 0.3 & $0.95 t^{-0.25}$ & 10,000 & 5.5 & 7 \\
\hline${ }^{226} \mathrm{Ra}$ & $\mathbf{W B}$ & 0.3 & 1.0 & & 0.3 & 900 & 590,000 & 110 & 70 \\
\hline $2>6_{\mathrm{Pa}}$ & Bone & 0.3 & 0.13 & & 0.04 & 16,400 & 590,000 & 110 & 7 \\
\hline $226_{R}$ & Bone & 0.3 & & 0.99 & 0.3 & $0.54 t^{-0.52}$ & 590,000 & 110 & 7 \\
\hline $234 \mathrm{U}$ & Bone & 0.0001 & 0.11 & & $1.1 \times 10^{-5}$ & 300 & $9.1 \times 10^{7}$ & 240 & 7 \\
\hline${ }^{234} \mathrm{~J}$ & Bone & 0.0001 & & 0.85 & $8: 5 \times 10^{-5}$ & $0.72 t^{-0.8}$ & $9.1 \times 10^{7}$ & 240 & 7 \\
\hline${ }^{238} \mathrm{U}$ & Bone & 0.0001 & 0.11 & & $1.1 \times 10^{-5}$ & 300 & $1.6 \times 10^{12}$ & 220 & 7 \\
\hline $238_{y}$ & Bone & 0.0001 & & 0.85 & $8.5 \times 10^{-5}$ & $0.72 t^{-0.8}$ & $1.6 \times 10^{22}$ & 220 & 7 \\
\hline${ }^{239} \mathrm{Pu}$ & Bone & $3 \times 10^{-5}$ & 0.8 & & $2.4 \times 10^{-5}$ & 73,000 & $8.9 \times 20^{6}$ & 270 & 7 \\
\hline${ }^{239} \mathrm{Pu}$ & Bone & $3 \times 10^{-5}$ & & 0.9 & $2.7 \times 10^{-5}$ & $0.99 t-0.01$ & $8.9 \times 10^{6}$ & 270 & 7 \\
\hline
\end{tabular}

Table A lists the parameters used in our dose calculations.

Table A. Purameters Used for Dose Calculations

Whole body. 